\title{
Judeus de Castela em Portugal no final da Idade Media: onomástica familiar e mobilidade
}

\author{
María José Ferro Tavares" \\ Universidade Aberta (r.)
}

\begin{abstract}
Judíos de Castilla en Portugal a finales de la Edad Media: onomástica familiar y MOVILIDAD.- Mediante el recurso a documentación en buena medida inédita de la cancillería real y procesos inquisitoriales, la autora realiza una lectura diacrónica de la presencia y establecimiento de judíos de origen hispánico en Portugal desde la instauración de la Casa de Avís y hasta después del bautismo forzado de 1497. La primera parte del estudio está dedicada al análisis de la onomástica hispano-judía, partiendo de la premisa de que el sobrenombre de algunos judíos puede indicar su naturalidad u origen toponímico (o el de sus antepasados inmediatos), con especial detenimiento en las familias Navarro, Menir (desmiente la tradicional identificación entre ambos linajes) y Abravanel. En la segunda parte se exponen ejemplos de la movilidad de los judíos llegados al reino como consecuencia de la inestabilidad social y las políticas regias.
\end{abstract}

Palabras Clave: historia de los judíos; Portugal; onomástica; movilidad; cambio social y cultural.

Castilian Jews in Portugal at the End of the Middle Ages: Familial Onomastics AND MoBILITY.- Using mainly unpublished sources of the royal chancery and Inquisition proceedings the author provides profiles of individuals and their families among a Jewish minority of Spanish origin in Portugal from the restoration of the Avis dynasty (1383) to the forced baptism and the expulsions and forced baptism of the Jews. The first part identifies Spanish-Jewish last names found in the sources as the last names of many Jews could indicate their geographic origin or that of their immediate ancestors. Special attention is given to a selection of these families (Navarro, Menir, Abravanel). In the second part, it is exemplified the mobility of the Jewish immigrants as a consequence of the social and political instability.

KeYwords: History of the Jews; Portugal; Onomastics; Mobility; Social and Cultural Change.

\footnotetext{
"mariajosetavares@gmail.com
} 


\section{NOMES E APELIDOS DE JUDEUS PORTUGUESES ${ }^{1}$}

Este tema não é de fácil percepção, devido à existência de uma onomástica dos judeus de origem hispano-portuguesa e menos de uma onomástica específica de cada reino peninsular. De facto, o povoamento judaico em Portugal aumentou na segunda metade do século XIV, devido à grande migração dos judeus navarros, aragoneses e castelhanos provocada por políticas e movimentos antijudaicos de raiz popular e/ou religiosa. Daí a grande variedade de apelidos de famílias que se fixaram no território, gerando novas comunidades ${ }^{2}$.

Infelizmente, a documentação conhecida não nos permite alicerçar com segurança muitas das nossas afirmações sobre o nome e os apelidos dos judeus a residir no espaço nacional. O nome próprio judaico é facilmente identificável porque se distingue do nome próprio cristão. Era impensável, ou, pelo menos nunca encontrámos, um cristão chamado José, Abraão ou Moisés. Por seu lado, os judeus usavam os nomes bíblicos de preferência, como Abraão, David, Jacob, Salomão, Aarão, Isaías, Eleázar, Judas, Moisés, Isaac, José, Saul, Daniel, Samuel, Benjamim, Simão, Baruc, Ruben, Ester, Miriam ou Mira, Ana, etc, a que se juntavam outros como Guedelha, Suas, Meir, Menaém, Façam, Haim, Necim ou Nacim, Sem Tob, Anto ou Ianto, e, para as mulheres, Ouro, Aviziboa, Cete, Tamar, Benvinda, Rica, Sol, Luna, Mazalto, Dona, Gemila ou Jamila, Velida, Rina, Cinfa, Lediça, Bela, Alegria, Missol, Formosa, Estrela, Abigail, Aljofar, Amada, Clara, etc.

Algumas famílias tinham preferência por alguns nomes próprios. Os Negro (Ibn Iahia) abusavam de Guedaliah, David, Salomão, Abraão, Judas, Jacob. Os Navarro preferiam Moisés, José, Juda, Isaac, Salomão e excepcionalmente Guedaliah, Esdras, Eleázar ou Haim. Os Abravanel optavam pelos nomes de Isaac, Juda, Samuel, José, Ya (Jacob?). Por ve-

\footnotetext{
${ }^{1}$ Em 2009 aflorei a questão da mobilidade num colóquio ocorrido em Coimbra. Veja-se: $\mathrm{M}^{\mathrm{a}} \mathrm{J}$. Ferro TAVARES, «Judeus e Cristãos-Novos nas Beiras - Retalhos de um quotidiano», in Coimbra Judaica. Actas (Coimbra, 2009), 43-97; EADEM, «The Castilian Jews in Portugal: an Approach to their History», Hispania Judaica Bulletin 7 (2010), 175-192. En 2011, no regresso da uma conferência no CSIC onde falei sobre os judeus castelhanos em Portugal, resolvi retomar o tema.

${ }^{2}$ Não iremos carregar o texto com notas extensas. Cingir-nos-emos apenas à indicação das fontes que acrescentaremos com a bibliografia fundamental sobre o assunto, sempre que necessário.
} 
zes, a mudança do nome próprio mais comum tinha a ver com o cruzamento entre famílias diferentes. Foi o caso de Guedelha nos Navarro, pelo cruzamento desta família com os Negro, por exemplo.

O mesmo sucedia com os apelidos de família, onde aos bíblicos como Cohen, Levi, Benjamim, Neemias, Baruc, se juntavam os Barzilai, Abulafia, Abeacar ou Abeatar, Abenazo ou Benazo, Naaman, Cavaleiro, Cide, Cidecairo, Cidelo, Gabay, Almale, Ambram, Esquerra, Soleima, Tobi ou Tovi, Amado ou Amato, Azecri, Matrotel, Mocatel, Abet, Adret, Saba, Caro, Adida, Alfaquim ou Alhaquim, Boino, Sassan ou Sasson, Benveniste ou Veniste, Samaia, Zarrel, Naar, Mardocai, Usque, Yom Tov (traduzido por 'Bom dia'), etc., entre muitos outros. Mas, para além destes, os judeus utilizaram o recurso aos topónimos da naturalidade da família os quais fariam esquecer o seu apelido original. Assim, encontramos os apelidos associados à toponímia da naturalidade, quer na forma adjectivada, como Navarro, Aragonês, Castelhano, Catalão, Galego, Toledano, Soriano, Segoviano, Zamorano ou Samorano, Sevilhano, Barcelonim, Valencim, Malagui, Carmonin, Ledesmim, quer antecedidos da preposição «de» e a identificação do reino, da cidade ou vila, de Leão, de Ávila, de Medina, de Molina, de Burgos, de Valladolid, de Carrión, de Estela, de Vitória, de Nágera, de Illescas, de Toro, a que se juntavam sem qualquer elemento semântico de ligação os Lerma, os Vilalobos, os Montesinho, etc.

Mas a mobilidade também ocorria no interior de cada reino, arrastando consigo, no caso português, o topónimo da naturalidade: de Tomar, de Leiria, de Coimbra ou Coimbrão, de Beja, de Seia, de Gouveia, de Faro, de Vila Real, do Porto, de Viana, da Pederneira, de Aveiro, Beirão, etc. Em alguns casos, o topónimo é de problemática localização devido à existência de vilas com o mesmo nome em Portugal e em outros reinos hispânicos. Cito os exemplos de Salvaterra, Benavente, Vila Real ou Viana.

Outras vezes, o apelido reflecte outras migrações com base em expulsões da minoria dos respectivos reinos ou deslocações em negócios, como Sarfati ou Franco, Inglês, Marracoxim, Anconina, Corsim, de Narbona, de Fez, etc. ${ }^{3}$.

\footnotetext{
${ }^{3}$ A relação onomástica/mobilidade foi por mim aflorada durante a discussão, após a minha conferência, no colóquio Minorias étnico-religiosas na Península Ibérica, períodos medieval e moderno, coord. $\mathrm{M}^{\mathrm{a}} \mathrm{F}$. Lopes de Barros e J. Hinojosa Montalvo (Évora: Colibri, Cidehus, Universidad de Alicante, 2006). Não recordo o conferencista
} 
Também sucedia que o nome próprio podia ser usado como apelido. Era o caso de Guedelha, Benjamim, Meir, Neemias, Ruben, Alegria, Gabriel, Daniel, Saul, Juda, etc.

Noutro caso era a profissão ou o instrumento profissional que passava a apelido. Por exemplo, José Vara, tirava o seu apelido da «vara» com que media as peças de pano no seu trabalho de alfaiate, ou os Mesteiral em Abrantes, ou Pimenta em Arronches e Elvas, ou o Alcaide, em Coina, ou os Caldeirão, em Évora, ou o Arqueiro, em Faro, ou o Prateiro, em Leiria, ou Ferreiro, em Lisboa. Outras vezes era uma característica pessoal que de alcunha se tornava em apelido, como Galante, Beiçudo, Goliardo, Querido, Ruivo, Pardo, Calvo, Calado, Alegre, Rico, Neto.

Por vezes, o nome tinha raiz árabe, como Soleima, Alhaquim ou Alfaqui, por exemplo.

Excepcionalmente, o apelido recordava aves, animais ou árvores, como Pinto (ou Polho - esp. 'pollo'), Falcão, Pardal, Vaca, Bácoro, Cachorro, Gato, Lobo, Pereira, Pinheiro, ou o nome próprio imitava a onomástica em moda na cristandade como o judeu Tristão de Elvas, ou mostrava influência de apelidos cristãos como Marcos ou Nunes. Acontecia também que o indivíduo judeu era identificado pelo nome próprio e por uma alcunha, como por exemplo Jacob, «cabeça de ferro», em Lisboa, ou José «cega raposas», morador também nesta cidade.

Já mais rara era, na documentação portuguesa, a identificação, pela expressão «ben ou aben» ('filho de'), com o progenitor. Neste caso, desaparecia, na maior parte dos casos o apelido. Ex: Samuel Aben Haim, ferreiro em Abrantes, ou o físico e rabi na Covilhã, Salomão Aben David. Já tal não sucedia no Alandroal, onde viviam os Acara e onde José Acara era

que da assistência associou a mobilidade com a pertença a uma sinagoga/escola, mas recordo que a minha questão e a do Prof. Hinojosa ficaram sem resposta, pelo que desconheço a ligação da mobilidade às escolas. Embora não sejam estudos específicos sobre a onomástica judaica, remeto o leitor para alguns trabalhos onde aparecem listados, ou não, nomes de famílias judaicas peninsulares: $\mathrm{M}^{\mathrm{a}} \mathrm{J}$. Ferro TAVARES, Os Judeus em Portugal no século XV (Lisboa: INIC, 1985), vol. II; J. CARRASCO et alii, Navarra Judaica. Los judíos del reino de Navarra (Pamplona: Gobierno de Navarra, 1995-), vols. I-VII; P. León Tello, Los judíos de Ávila (Ávila: Diputación, 1965); Ídem, Judios de Toledo (Madrid: CSIC, 1979); J. Rodríguez Fernández, Las juderías de la provincia de León (León: Centro de Estudios e Investigación San Isidoro, 1976); L. SuÁrez Fernández, Documentos acerca de la expulsión de los judios (Valladolid: CSIC, 1964). 
identificado por ser filho de Sem Tob Acara. Daí a nossa dificuldade na criação de genealogias judaicas. Dificuldade que nos surge acrescida da existência de nomes e apelidos iguais na mesma geração ou em gerações muito próximas. Também dificulta a distinção entre homónimos o facto de desconhecermos as datas de nascimento ou de falecimento, assim como os progenitores. Para um melhor conhecimento necessitaríamos de poder ter tido acesso à documentação das chancelarias das comunas portuguesas que infelizmente desapareceu.

O nome era, sem dúvida, importante. Daí que na diáspora quinhentista, apesar do nome cristão imposto, o nome judaico sobrevivia clandestinamente no interior das famílias e viria à superfície quando se assumiam judeus em Ferrara, Ancona ou na Turquia. O nome reflectia uma identidade, a pertença a uma família, a uma «casa», a uma terra, a um reino. Mas esta identidade pessoal aparecia carregada pela pertença a uma tradição religiosa e cultural, a uma língua, a uma sinagoga. E, se não temos tanto esta consciência, no tempo em que os judeus podiam viver livremente a sua religião, a sua identidade como povo, mesmo em diáspora, irrompia importante para a consciência da identidade dos judeus sefarditas após o baptismo e a sua consequente diáspora. Sinagogas onde se falava e rezava em português, onde se liam os textos sagrados na língua de origem ou no ladino, legais como em Ferrara ou na turca Esmirna, ou clandestinas como nas casas particulares da Rua Nova de Antuérpia ou em França eram, com a memória do nome hebraico usado como alcunha ou apelido, sinais dessa identidade, dessa pertença a uma família, um território, um reino, uma tradição. Era a memória da Sefarad na sua diáspora imposta.

\subsection{A mobilidade dos judeus e o nome da família}

A mobilidade era uma característica do povo judaico e era mais fácil na Sefarad em cujo território havia uma afinidade linguística entre os reinos cristãos, para além da língua comum religiosa, o hebraico, e uma afinidade cultural entre estes e o reino muçulmano de Córdova ou o de Granada, mais tarde. Em todos eles residiam judeus poliglotas que circulavam com facilidade entre uns e outros reinos, fossem eles cristãos ou islâmicos, e se acolhiam nas diversas judiarias, pretextando relações familiares para apoio aos negócios, ou para a obtenção de informações 
políticas ou como intermediários, emissários ou diplomatas, ao serviço do seu senhor. O domínio das línguas vernaculares cristãs e do árabe tornavam-nos servidores preciosos ao serviço dos reis peninsulares.

Mas a mobilidade de alguns judeus e suas famílias também se justificava pela pertença ao serviço da família real, deslocando-se, por isso, integrados na comitiva de infantes e infantas. Tal aconteceu com um judeu castelhano que veio para Portugal como almoxarife na comitiva da rainha D. Urraca, mulher de D. Afonso II, e se converteu ao cristianismo com o nome de Rui Capom, tendo como recompensa sido feito cavaleiro pelo rei. Uma filha, segundo o conde D. Pedro de Barcelos, ou neta do cavaleiro Rui Capom, segundo o anónimo autor do Livro Velho, casaria com o fidalgo Gonçalo Pais Taveira, levando em dote uma grande riqueza. Por sua vez Rui Capom casaria com uma rica cidadã lisboeta ${ }^{4}$. Encontraremos, mais tarde, uma família judaica de Santarém que assumirá o apelido Capão, mas desconhecemos a eventual ligação familiar ao almoxarife de D. Urraca ${ }^{5}$.

Assim, ao abordarmos este assunto, devemos ter em atenção, em primeiro lugar, o facto de qualquer judeu necessitar de permissão régia para residir em Portugal ou para aqui vir transitoriamente em negócios, ou até para sair do reino. No primeiro caso, estamos perante aquilo a que a documentação designou por carta de contrato a qual munia um indivíduo do consentimento para habitar no reino, nele circular livremente, exercer um ofício, negociar, arrendar uma casa numa judiaria ou, excepcionalmente, em ruas de um concelho ou comprar bens móveis e imóveis e poder transaccioná-los ${ }^{6}$. No segundo caso, o judeu em trânsito necessitava de uma carta régia de segurança que lhe concedia a protecção real.

${ }^{4}$ Livro de Linhagens do conde D. Pedro, ed. J. Mattoso, in Portvgaliae Monvmenta Histórica $[=P M H]$, Nova Série [= NS], vol. II/1 (Lisboa: Academia das, 1980), 489; Livro Velho, in PMH, NS, vol. I [= Livros Velhos de Linhagens], ed. J. PIEL e J. Mattoso (Lisboa, 1980), 57, tit. II (Maias).

${ }^{5}$ Tavares, Os Judeus em Portugal no século XV, vol. II, 333, 334 e 335 . Os ferreiros Samuel Capão, Haim Capão e Judas Capão aparecem entre os moradores da judiaria de Santarém, na segunda metade do séc. XV. Capão aparece-nos como apelido, mas podia ser alcunha derivada do exercício da profissão de capador.

${ }^{6}$ Encontrámos diversos exemplos de cartas de contrato individuais nos contratos de aforamento em Santarém: Santarém, Arquivo da Misericórdia, Hospital de S. Martinho, maço $1, n^{\circ} 5, n^{\circ} 15$, por exemplo. 
A carta de contrato, comprada por um judeu que decidisse viver no reino e que acabava por funcionar como um autêntico privilégio, destinava-se a conferir-lhe os mesmos benefícios que a um indivíduo natural do reino. Pertencia a um núcleo de cartas régias gerais, concedidas a cada comuna e vulgarmente confirmadas de rei a rei como carta de privilégio dirigida «à comuna dos judeus de», cujo teor na íntegra se perdeu, mas que devia referir a pertença a um senhor, neste caso, o rei, o usufruto da liberdade religiosa, a permissão para se regerem pelo direito talmúdico em pleitos entre judeus ou quando o judeu fosse réu, manterem a sua tradição, os impostos que deveriam pagar ao senhor, ao concelho e à Igreja, a liberdade de circulação, de trabalho e fixação num determinado concelho, etc. Enquanto as cartas de privilégio se destinavam a uma comunidade, as cartas de contrato eram individuais e eram «compradas» por cada judeu e destinavam-se a dar-lhe a permissão para se movimentar livremente no reino, num concelho e transaccionar bens móveis e de raiz. Posteriormente, estas mesmas cartas pessoais de contrato seriam atribuídas genericamente às comunas que as redistribuíam por cada judeu que atingisse a idade adulta ou recém-vindo que nelas residisse, em troca de um pagamento.

Os apelidos de Leão, Navarro, Castelão, de Valladolid, de Alcântara, de Sevilha, de Toro devem ter sido os mais antigos de origem toponímica peninsular não portuguesa encontrados no reino, pois, infelizmente, a documentação referente a judeus nos séculos XIII e XIV não foi pródiga em indicar os apelidos, senão muito raramente ${ }^{7}$. Eles acompanharam o crescimento da população judaica no reino e o aumento do número de judiarias, a partir de finais do século XIII. Foi já no final desta última centúria que o uso do apelido passaria a ser mais frequente na documentação.

Apesar de D. Dinis ter povoado Bragança com judeus, apenas um reduzido número de judeus e judias, que podemos deduzir fossem marido e mulher, pelo menos, aparecia mencionado. Apenas sabemos que eles deveriam investir 3.500 maravedis leoneses brancos da guerra de oito no soldo em vinhas, herdades e casas $^{8}$. A menção ao dinheiro utilizado no pagamen-

${ }^{7} \mathrm{M}^{\mathrm{a}} \mathrm{J}$. Pimenta Ferro [TAVAres], Os Judeus em Portugal no século XIV (Lisboa: IAC, 1970),131-135 e apêndice II.

${ }^{8}$ Lisboa, Arquivo Nacional da Torre do Tombo [= IAN/TT], Chancelaria de D. Dinis, liv. 1, fl. 57v; Ferro [TAVAres], Os Judeus em Portugal no século XIV, 46. 
to poderá fazer-nos supor que estes judeus proviessem do reino de Leão ou de Castela, mas não é uma garantia certa pois a moeda leonesa-castelhana circulava ao longo da raia portuguesa ao lado dos dinheiros portugueses. Mas, para além deste investimento no território, os judeus de Bragança ficavam obrigados a dar, anualmente, ao rei 800 libras ${ }^{9}$. Infelizmente, este grupo de povoadores era apresentado pelo nome próprio, excepto um judeu que é identificado como Moisés Rodrigo e um outro como Montesinho que pode ser apelido. Para o século XV, verificamos a existência de famílias com apelidos de origem toponímica como de Leão, Burgalês, Vilhedigo (talvez Villadiego, próximo de Burgos), Segoviano, Saragocim, Sevilhano, a par de muitos outros apelidos de onde destacamos os Cema, os Adida, os Machorro, Calado, Tovi, Boino, Ruivo, Cide, Abdias, Aboa, etc. ${ }^{10}$.

Em 1294, nas confrontações de uma casa aforada a José, judeu, neto de D. Maior, na judiaria velha de Lisboa junto à porta do Chancudo, encontramos a menção a uma Dona, viúva de Jufez Castelão, e a um Isaac Pardo $^{11}$. Já na judiaria da Guarda, recém criada, D. Dinis aforava, pela mesma altura, a Moisés de Valladolid e a Ourocete, sua mulher, duas casas por cinco morabitinos de quinze soldos, o morabitino ${ }^{12}$. Este foro distinguia-se de outros pela moeda utilizada que não era a de dinheiros portugueses, podendo nós pressupor que o rei procurava agilizar estes aforamentos nas judiarias recentes aceitando a moeda conhecida pelos recém chegados ao reino. Outro judeu castelhano que se fixou na Guarda foi Isaac de Cáceres e a sua mulher Lediça ${ }^{13}$.

No povoamento da judiaria nova ou das taracenas em Lisboa por D. Afonso IV, encontramos o aforamento de um sobrado feito a Samuel de Alcântara $^{14}$. Um Jacob de Leão e a mulher Justa aforavam uma tenda em Beja que, após o falecimento de ambos, passaria para a filha Lediça ${ }^{15}$.

${ }^{9}$ IAN/TT, Chancelaria de D. Dinis, liv. 3, fls. 104r-v.

${ }^{10}$ Tavares, Os Judeus em Portugal no século xv, vol. II, 31-35.

${ }^{11}$ IAN/TT, Chancelaria de D. Dinis, liv. 2, fl. 85v; Livro $1^{\circ}$ dos Bens Próprios dos Reis e das Rainhas, fls. 90r-v.

${ }^{12}$ IAN/TT, Chancelaria de D. Dinis, liv. 2, fl. 113r.

${ }^{13}$ IAN/TT, Chancelaria de D. Dinis, liv. 4, fl. 29v.

${ }^{14}$ Chancelarias Portuguesas. D. Afonso IV (Lisboa: INIC, Centro de Estudos Históricos, UNL, 1990), vol. I, 115 (doc. 103).

${ }^{15}$ Chancelarias Portuguesas. D. Afonso IV, vol. II, 292r-293r (doc. 183). 
Já no reinado de D. Fernando, aparece-nos como foreiro de uma loja na judiaria nova das taracenas, em Lisboa, um Abraão de Touro que aqui também trazia casas do rei, enquanto José Catalão arrendava um sobrado na mesma rua dos judeus e próximo da sinagoga desta ${ }^{16}$. Em 1381, um dos rendeiros das sisas gerais de Sarzedas e Sovereira Formosa era Abraão de Molina, residente em Castelo Branco. Outro rendeiro, este da portagem de Coimbra, era D. Caper de Leão. Por sua vez, Moisés de Leão, morador em Évora, arrematava com Rabiça (Rabi Çag?) Zabona as sisas gerais e as sisas do vinho de um soldo o almude, e, sem parceiro, fazia o lanço nas mesmas rendas da vila de Serpa ${ }^{17}$.

Mas, juntamente com estes apelidos de origem toponímica, o aumento da população judaica em Portugal fazia surgir, em conjugação com o aumento do número das fontes disponíveis, os Amado, os Alhaquim, os Acequerim, os Azecri, os Adaroque, os Sapaio, os Querido, os Gago, os Alferce, os Preto, os Alcaide, os Belhamim, os Benafaçam, os Zaboca, os Usque, os Zarrel, os Aliote e muitos outros a partir deste final de Trezentos, cuja naturalidade desconhecemos.

Infelizmente não temos a identificação dos rendeiros anteriores ao reinado de D. Fernando, com excepção dos Negro e os seus sub-rendeiros judeus, numa cantiga de mal-dizer de Estêvão da Guarda e de D. José (Negro) ${ }^{18}$, para podermos fazer comparações e tirar conclusões sobre se os recém vindos eram mais ricos que as demais famílias judaicas há mais tempo radicadas no reino ou dele naturais. No entanto, podemos dizer sem grandes dúvidas que, nos séculos XIII e XIV, duas famílias se distinguiram com poder financeiro, os Negro (Ibn Yahia) e os Alhaquim a que se juntaria D. Juda Aben Menir, como veremos. Os Navarro apareciam mais como grandes latifundiários e menos como investidores nas rendas reais, que o saibamos. No século XV, outras famílias se distinguiriam como mercadores, rendeiros e credores do rei ou da alta nobreza, como os Abravanel, os Toledano, os Catalão, entre outras cuja proveniência segura desconhecemos como os Palaçano e os Latam.

${ }^{16}$ IAN/TT, Chancelaria de D. Fernando, liv. 1, fls. 29v, 137r-v.

${ }^{17}$ IAN/TT, Chancelaria de D. Fernando, liv. 3, fls. 3r, 19r-v, 37r, 46r.

${ }^{18}$ Cantigas d'escarnho e de mal dizer dos cancioneiros medievais galego-portugueses, ed. Rodrigues LAPA (Lisboa: Galáxia, 1970), 203-205 (§ 126). 


\subsection{Os Navarro, os Menir e os Leiria}

Dos apelidos de origem peninsular, o mais conhecido foi o nome Navarro dado a famílias judaicas que entraram em Portugal no reinado de D. Dinis, provenientes de Navarra. Não nos parece que o nome surgisse, no caso destes judeus, como alcunha senão seria antecedido de «dito Navarro», mas sim já como apelido tal como acontecia com os outros topónimos acima referidos. Não nos esqueçamos que este nome «Navarro» era já, no século XIV, apelido neste reino, como podemos confirmar entre as inúmeras referências onomásticas de origem toponímica que encontrámos na obra de Juan Carrasco ${ }^{19}$.

Os Navarro apresentaram-se dispersos no território português. Se o seu prestígio se iniciou em Lisboa, como veremos, a verdade é que nos finais de Trezentos os encontrámos, também, em Évora e no século XV estavam radicados em Abrantes, Arronches, Beja, Castelo Branco, Covilhã, Coimbra, Guarda, Gouveia, Setúbal, Torres Novas, Trancoso e Viseu. Que poderemos dizer acerca deles? Uma família? Várias famílias com apelido Navarro? Que relação familiar tinham umas com as outras? Ou o que as unia era apenas a Navarra como reino da naturalidade? Infelizmente não sabemos dar uma resposta, excepto que o cruzamento pelo casamento ocorreu, em alguns casos, entre os Navarro de Lisboa e os Navarro de Évora.

A família fixou-se em Lisboa, na Pedreira, no início do século XIV (1303). O aforamento das casas novas que tinham sido «escolas» foi feito por D. Dinis a uma família alargada de judeus navarros, cujos laços entre si desconhecemos na generalidade para além de, na sua maioria, terem em comum o apelido Navarro. Judas Navarro e Reina, sua mulher, José Navarro e Mira, Moisés Navarro e Solouro, Salomão Navarro e Amada, Abraão e Aviziboa e respectivos filhos, Isaac, filho de Judas, casado com Aviziboa, Isaac, filho de José, e, ainda, José e Isaac filhos de Belecide, instalavam-se numa zona da cidade no exterior da designada judiaria ve$\mathrm{lha}^{20}$, que alguns autores chamariam a judiaria da Pedreira, mas que nunca

${ }^{19}$ Los judios del reino de Navarra. Documentos. 1334-1350 [= Navarra Judaica 2], eds. J. Carrasco, F. Miranda García, E. Ramírez Vaquero (Pamplona: Gobierno de Navarra, 1995), 121 (Nauarro de Lerín), 205, 236, 275 (Gentó Nauarro).

${ }^{20}$ IAN/TT, Chancelaria de D. Dinis, liv. 4, fls. 25v-26r. 
foi rua nem bairro de judeus, embora possamos supor que o rei tivesse pensado erguer naquele espaço uma judiaria.

Em suma, estamos, provavelmente, perante vários membros de uma mesma família originária de Navarra que usaria já, ou não, o apelido Navarro e de uma outra família, constituída pelos dois filhos de Belecide que não tinham o apelido Navarro ou, pelo menos, este não foi mencionado no documento régio, e que decidiram aforar o antigo paço das Escolas Gerais em Lisboa, mantendo-o como residência até o rei querer doar todo o campo da Pedreira, incluindo as casas e os terrenos circundantes, ao almirante Manuel Pessanha, em $1317^{21}$.

Pressupondo que seriam irmãos, traçámos este quadro genealógico, infelizmente de difícil cruzamento com os futuros Navarro. Excluímos dele Belecide e os filhos porque não são identificados no documento com este apelido.

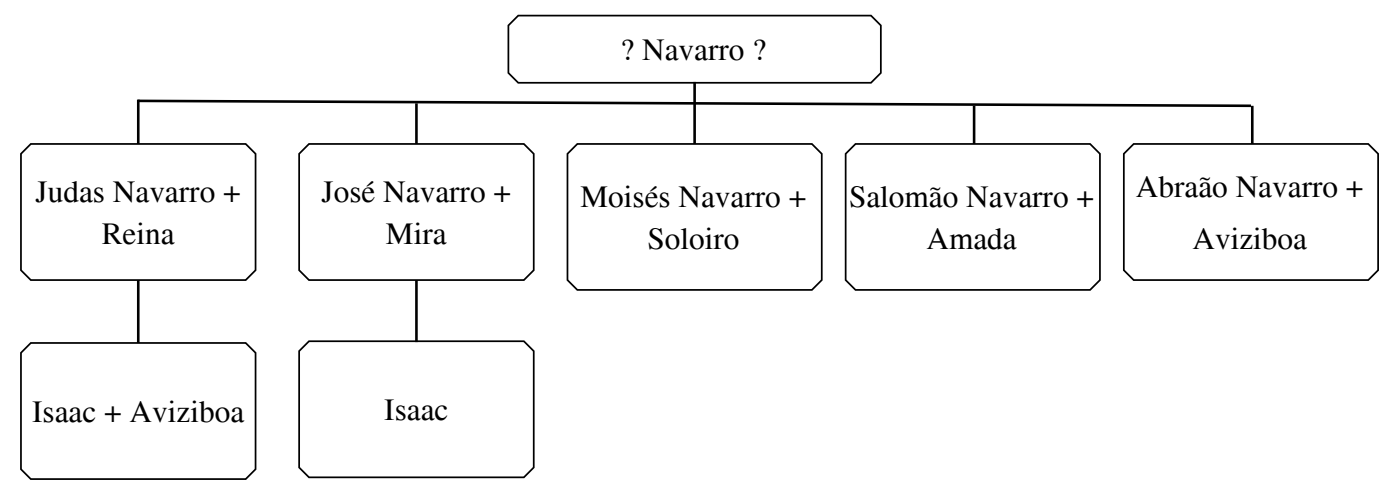

Em 1306, o monarca comprava a Judas Navarro e a Reina uma quinta em Água dos Peixes, nos arredores de Alvito, constituída por pomar, vinha, casas e uma azenha por quatrocentas libras de dinheiros portugueses. À escritura da venda testemunhavam dois judeus, Salomão Cabeça e José, ourives ${ }^{22}$.

A razão da mobilidade em direcção a Portugal deste grupo de judeus, oriundos de Navarra e supostamente parentes, é-nos desconhecida. Ape-

${ }^{21}$ IAN/TT, Chancelaria de D. Dinis, liv. 3, fl. 108; Chancelarias Portuguesas. D. Pedro I (Lisboa: INIC, Centro de Estudos Históricos, UNL, 1984), 30 (doc. 65).

${ }^{22}$ IAN/TT, Livro $2^{\circ}$ dos Direitos Reais, fl. 200v. 
nas podemos afirmar que é anterior à matança de 1328, apesar de alguma instabilidade social resultado da instabilidade política se ter feito sentir episodicamente durante o século XIII. Teria sido talvez o receio de levantamentos populares e de exacções dos poderosos sobre as gentes da minoria que fez este grupo movimentar-se em direcção a Portugal onde um rei decidira povoar o seu território com judeus.

Desconhecemos o que ocorreu aos Navarro durante o reinado de D. Afonso IV, pois estão totalmente omissos na documentação real que nos chegou. A única família judaica cortesã, tal como acontecera nos reinados anteriores, era a dos Negro (Ibn Yahia) onde permanecia o arrabiado mor, passado de pai a filho. Ao contrário de alguns autores que associam os Menir aos Navarro, a documentação nada nos diz que tal possa ser afirmado com segurança histórica e ainda muito menos que o rabi mor de D. Dinis e de seu filho fosse Juda Aben Menir ${ }^{23}$. D. Juda, rabi mor, era filho de Guedelha, rabi mor, e estes pertenciam à família dos Negro (Ibn Yahia). Guedelha Negro, filho daquele, seria rabi mor no tempo de D. Afonso IV e cairia em desgraça junto de D. Pedro I, pois teria apoiado o assassinato de Inês de Castro. Prova desta queda era a doação da sua quinta em Frielas a mestre Vivas, judeu, médico do infante D. João, filho da Castro e de D. Pedro e, mais tarde, uma quinta do rabi mor Guedelha Negro seria doada a Inês Afonso, criada do rei ${ }^{24}$.

Em Junho de 1361, D. Pedro I aforava umas vinhas no campo de Alvalade em Lisboa, as quais confrontavam com vinhas que Moisés Navarro aí possuía, sem qualquer referência a que fosse rabi mor ${ }^{25}$. Mas, em Setembro, na sequência da resolução tomada nas cortes de Elvas deste mesmo ano, sobre a duração dos mandatos dos rabis, vereadores e procurador das comunas dos judeus, Moisés Navarro aparecia como rabi-mor

${ }^{23}$ R. FAINGOLD, «Los judíos en las cortes reales portuguesas», Sefarad 45 (1995), 77-104 (versão portuguesa online em servidormix.com/ redejudi/images/livros/judeusnascortes. pdf). Este texto apresenta-se cheio de erros cronológicos e de confusões entre, por exemplo, Juda Negro, rabi mor de D. Dinis, e Juda Aben Menir, rabi mor de D. Fernando, e Moisés Navarro, físico e rabi mor de D. João I, em vez de Mestre Moisés de Leiria. Coloca a criação da sinagoga de Monchique no Porto no reinado de D. Dinis e não no de D. Fernando e associa Jacob Negro, irmão de Juda Negro, a Juda Aben Menir. Tem outras confusões, sobre as quais não cremos valer a pena determo-nos porque extravasam o nosso tema.

${ }^{24}$ Chancelarias Portuguesas. D. Pedro I, 157 (doc. 398), e 486-487 (doc. 1027).

${ }^{25}$ Chancelarias Portuguesas. D. Pedro I, 274 (doc. 603), e 577, (doc. 1191). 
das comunas dos judeus do reino ${ }^{26}$. Poderemos concluir que a nomeação régia para o arrabiado mor de Portugal ocorreu entre Junho e Setembro?

Em Dezembro de 1362, o rei confirmava a instituição feita pelo rabi mor Moisés Navarro e Salva, sua mulher, do morgado dos seus bens nos dois filhos do casal, José e Isaac, para eles e os seus descendentes. A instituição privilegiava a varonia e os bens eram repartidos igualmente entre os dois filhos. No entanto, não excluía a legitimidade do acesso das mulheres ao morgado, mas punha-lhes uma reserva. Era necessário que elas casassem com judeus seus parentes de apelido Navarro. Era a constituição de uma linhagem que aqui surgia apoiada em propriedades rurais e bens urbanos em Lisboa e nos arredores, que passariam por varonia aos descendentes. A quinta no Montijo, a quinta em Carnaxide, casais, herdades, vinhas, pomares em Carnaxide, as casas com sobrados e torres, quintais e poços em que eles residiam em Lisboa e que tinham pertencido a Guedelha Negro, ex-rabi-mor, faziam parte do morgado de José Navarro. As casas, sótãos, sobrados e respectiva torre, quinta e paço sitos na judiaria velha de Lisboa que tinham pertencido a mestre José Navarro, pai do rabi mor, a quinta em Caspolima (Oeiras) com casas, herdades, vinhas, herdades e torre, a quinta em Palma, termo de Lisboa, com as suas adegas, casas, lagar, torres e vinhas seriam herdadas pelo filho Isaac Navarro. Os filhos deviam ser ainda menores pois Moisés Navarro e Salva estabelecem como tutor, em caso de morte de ambos, Salomão Alegria. Os instituidores justificavam a criação dos dois morgados para evitar que a riqueza familiar perecesse, demitindo-se Salva dos bens que pertenciam às suas arras a favor dos filhos, com a condição de estes manterem a condição social da mãe, se viúva ${ }^{27}$.

Se associarmos o rabi mor aos Navarro do tempo de D. Dinis teremos como hipótese o seguinte parentesco, apesar de nenhum destes aparecer como mestre José Navarro. Apenas uma das famílias do grupo era encabeçada por um José, casado com Mira e que tinha Isaac como filho. Podemos supor que Moisés, a ser filho do casal, ainda não teria nascido ou seria criança, pelo que não nos aparecia referenciado. Por outro lado, verificamos que os filhos do rabi mor, José e Isaac, seguem a atribuição

\footnotetext{
${ }^{26}$ Chancelarias Portuguesas. D. Pedro I, 299-300 (doc. 646).

${ }^{27}$ Chancelarias Portuguesas. D. Pedro I, 331-335 (doc. 733).
} 
do nome comum às famílias judaicas: o primogénito recebia o nome do avô paterno e o secundogénito podia receber o do tio paterno ou o do avô materno. Por outro lado, não conhecemos mais nenhum filho ao rabi mor Moisés Navarro, o que não quer dizer que não tenha podido existir. Mas aqui funcionamos no campo das hipóteses.

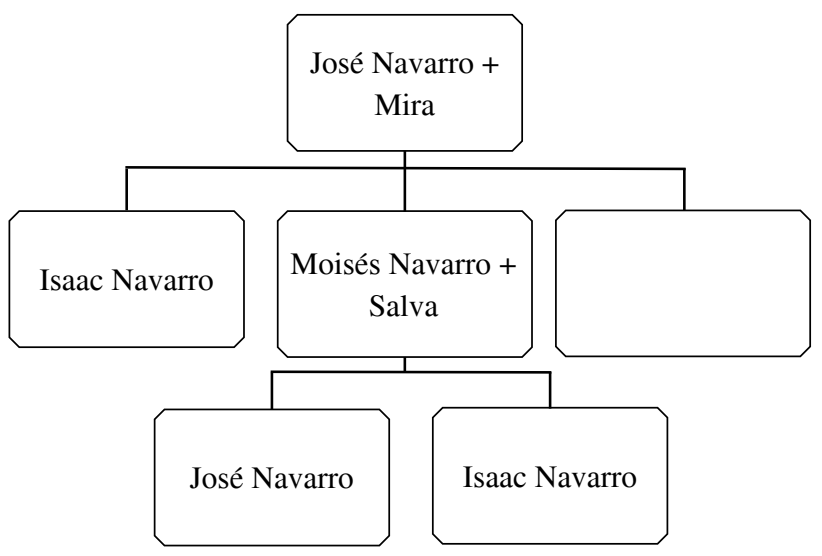

Ou seja, supomos que Moisés Navarro pertenceu a uma segunda geração destes imigrantes navarros e sabemos que sucedeu no cargo a Guedelha Negro que, ou teria já falecido em 1359 ou caído em desgraça junto de D. Pedro I, pois teve alguns dos seus bens confiscados e doados a mestre Vidal, físico do infante D. João, e a Moisés Navarro. Aparentemente teria havido uma vacatura no arrabiado mor de, pelo menos, dois anos. Sobre os Navarro, a restante chancelaria deste rei é totalmente omissa, o que não significa que a família não tivesse permanecido no reino ou multiplicado a sua descendência. Também desconhecemos a profissão de Moisés Navarro que Kayserling identificava como tendo sido cirurgião do rei, talvez por confusão com mestre Moisés de Leiria ${ }^{28}$. Temos dúvidas sobre esta afirmação pois, ao contrário de outros rabis e judeus que exerceram a medicina, Moisés Navarro nunca teve o nome antecedido de «mestre», nem foi identificado por «físico do rei». Por outro lado, Moisés Navarro não ocupou o arrabiado mor durante trinta anos e esta extensão de tempo só pode ser explicada pela associação ao rabi mor de D. João I.

${ }^{28}$ M. Kayserling, História dos Judeus em Portugal (S. Paulo: Pioneira, 1971), 23. 
O apelido Navarro mantinha-se no reinado de D. Fernando em alguns judeus, cuja ligação com a família do rabi mor desconhecemos. Um deles era Jacob Navarro, morador em Sintra que arrematava as sisas gerais e do vinho deste concelho, de Cascais, Chilheiros e seus termos ${ }^{29}$.

Em 1373, D. Fernando nomeava rabi mor dos judeus de Portugal D. Juda, sem especificação de apelido, e confirmava-lhe as competências que os anteriores rabis mores tinham recebido dos reis anteriores. Curiosamente, este era o primeiro rabi mor a ser designado na documentação da chancelaria real por «dom» ${ }^{30} \mathrm{e}$, se a memória não nos falha, foi o único, o que não significa que os seus sucessores no arrabiado não usufruíssem da categoria de cortesãos, vassalos do rei. Em 1375, o monarca conjuntamente com a rainha Leonor Teles doavam a D. Juda, tesoureiro do rei e rabi mor, em pagamento dos muitos serviços prestados, as casas do palheiro que estavam em ruínas, na Rua do Chancudo, as quais Moisés Navarro trouxera aforadas do rei, sem qualquer menção à existência de parentesco entre ambos. Pela mesma altura e nas proximidades destas, o rabi mor aforava umas casas régias no exterior da judiaria e próximo da porta do Chancudo ${ }^{31}$. Em 1378, D. Juda comprava em hasta pública umas casas que tinham pertencido a Abraão Marcos, Isaac Belhamim e David Tab, rendeiros, residentes em Lisboa, os quais as tinham perdido por dívidas à coroa ${ }^{32}$. Em 1380, o monarca ordenou a entrega de uns pardieiros junto a S. Nicolau e da judiaria velha, que tinham sido confiscados por dívida de José Romão e de seu irmão Salomão a D. Fernando ${ }^{33}$. No ano seguinte, recebia em doação perpétua metade da adega do rei, junto com a judiaria velha e que confrontava com a casa do rabi mor ${ }^{34}$. Em 1382, recebia do monarca umas casas em Santarém, na rua de S. João de Alporão, que eram contíguas a outras casas do rabi mor na mesma rua ${ }^{35}$. No ano seguinte, D. Fernando doava-

\footnotetext{
${ }^{29}$ IAN/TT, Chancelaria de D. Fernando, liv. 3, fls. 23v e 86r.

${ }^{30}$ IAN/TT, Chancelaria de D. Fernando, liv. 1, fl. 132r.

${ }^{31}$ IAN/TT, Chancelaria de D. Fernando, liv. 1, fls. 163r-v, 173r.

${ }^{32}$ IAN/TT, Chancelaria de D. Fernando, liv. 2, fl. 51r.

${ }^{33}$ IAN/TT, Chancelaria de D. Fernando, liv. 2, fl. 67r.

${ }^{34}$ IAN/TT, Chancelaria de D. Fernando, liv. 2, fl. 90r.

${ }^{35}$ IAN/TT, Chancelaria de D. Fernando, liv. 2, fl. 91v.
} 
-lhe mil libras das duas mil que os judeus lhe deviam pagar anualmente pelo tributo de dois soldos o almude de vinho judengo ${ }^{36}$.

Mas não era só D. Juda a auferir dos benefícios do soberano. Também D. Reina, sua mulher, recebia de D. Fernando umas casas na Rua do Inferno, em Lisboa, junto da praça onde se vendia o pão, ou seja, no exterior de qualquer um dos bairros judaicos. Mais tarde, permitir-lhe-ia aforar uma loja, sobreloja e sobrado na mesma rua e contíguas às casas que o rei antes lhe doara ${ }^{37}$.

Seria em documentos de 1382, que D. Fernando identificava o nome completo do seu tesoureiro e rabi mor: D. Juda Aben Menir. Tal sucedeu na carta que dizia respeito à equiparação do cargo de rabi mor ao de corregedor na corte e meirinho, permitindo-lhe que trouxesse cadeia e selo, e na doação de mais uma casa em Santarém, em pagamento de serviços prestados ${ }^{38}$.

Mas D. Juda tornara-se imprescindível ao rei de Portugal. Ele era seu tesoureiro ou tesoureiro-mor, noutros documentos, despachava a correspondência da chancelaria juntamente com o vedor da fazenda, era rendeiro-mor do reino tendo outros rendeiros judeus sob a sua dependência. Tudo o que dizia respeito a impostos era da sua estrita competência e despacho. Era um cortesão, tal como acontecera com os outros rabis-mores do reino. Era, de facto, um homem poderoso, favorito do soberano. Nunca até então, que o saibamos, um judeu tinha ascendido a tal poder, nomeadamente, numa época em que os sentimentos xenófobos cresciam nos reinos peninsulares e ameaçavam salpicar o equilíbrio social em Portugal, com o ataque à judiaria de Leiria durante a semana santa.

D. Juda prestou outros serviços à coroa portuguesa. É provável que já residisse no reino ou servisse o monarca, quando D. Fernando usou o estratagema da recolha das boas moedas de ouro e de prata, pagando-as com as moedas de guerra em lei fraca de bolhão, em 1369-70. Alguns autores, como Costa Lobo, sugeriam que tal medida só teria sido possível por conselho dos experientes mercadores e financeiros judeus. Entre estes estariam também os Negro, conhecidos por terem sido almoxarifes régios e rendeiros, como David Negro ou Salomão Negro, parceiro mas também

${ }^{36}$ IAN/TT, Chancelaria de D. Fernando, liv. 3, fl. 93r.

${ }^{37}$ IAN/TT, Chancelaria de D. Fernando, liv. 2, fl. 97v, liv. 3, fl. 42r.

${ }^{38}$ IAN/TT, Chancelaria de D. Fernando, liv. 3, fls. 6v, 7r. 
rival de D. Juda em certos negócios. Segundo Béatrice Leroy, o rabi mor de D. Fernando foi também um seu emissário junto da corte de Navarra e, por outro lado, um servidor secreto do rei de Navarra em Portugal. Navarra teria estado ao lado de Portugal contra Castela, no tempo de Henrique de Trastâmara. Mas D. Juda não foi o único a viajar entre os dois reinos. D. Reina, sua mulher, Juda Franco, homem do rabi mor, e ainda um certo Pedro, este, pelo nome, cristão, foram emissários enviados a Navarra pelo rabi mor em nome do monarca português ${ }^{39}$.

O seu poder era tão grande que tinha como paralelo o favor que o casal real lhe dispensava. D. Juda soube registar na pedra o seu panegírico. $\mathrm{Na}$ inscrição que se encontraria na sinagoga de Monchique, no Porto, que ele mandara construir, podia ler-se para memória futura:

Aquele que disser porque não se guardou esta casa com muralhas. / Que saiba que há para mim protector que priva com os ilustres da nobreza. / Comigo uma guarda? Dirá, eu sou toda e importante muralha. / Grande dos judeus, denominador dos grandes, e no estrado dos nobres está assentado; / braço bom para o seu povo, servo de Deus, fez construir uma casa para o seu nome de pedras talhadas. / Do rei o segundo, na proeminência ele se conta, na sua grandeza e com os reis faz conselho. / Ele é o Rab Don Jehuda Ben Menir, luz de Juda e dele suprema autoridade. / Por ordem do Rab, que viva, Don Joseph Ben-Arieh foi intendente principal da obra.

Nesta breve resenha, verificamos que D. Juda foi rabi mor e tesoureiro, pelo menos, desde 1373 a 1383. Os Navarro encontravam-se ausentes da esfera cortesã e nada nos permite relacionar D. Juda Aben Menir com aquela família, excepto que ambas provinham daquele reino. Amador de los Rios apresentava D. Juda, como filho de Moisés Navarro. Afirmava também que Moisés Navarro teria vindo para Portugal como resultado da matança dos judeus de $1328^{40}$. Infelizmente não declarou onde se baseou para criar esta genealogia que ligava Juda Aben Menir a Moisés Navarro, a qual não tem qualquer suporte na documentação portuguesa conhecida.

${ }^{39}$ B. Leroy, Les Menir. Une famille sépharade à travers les siècles (XII $-X X^{e}$ S.) (Paris: Éditions CNRS, 1985), cap. III, 47-56.

${ }^{40}$ Cf. J. Amador de los Ríos, Historia social, política y religiosa de los judíos de España y Portugal (Madrid, Aguilar, 1973²), 412, 418. 
Também nesta linha de pensamento esteve Mendes dos Remédios que o apresentava como D. Juda aben-Moisés Navarro e remetia para um documento da colecção Gavetas da Torre do Tombo (gaveta II, maço 2, doc. 9) para justificar esta ligação. Aqui, segundo este autor, estaria uma carta de venda de D. Juda e sua mulher Reina a D. Fernando da quinta de Água dos Peixes ${ }^{41}$. Infelizmente, este documento não existe em toda a colecção das Gavetas da Torre do Tombo e a venda da referida quinta está averbada na chancelaria de D. Dinis

Embora não nos consideremos detentores da verdade histórica, não nos parece que possamos associar D. Juda ao rabi mor Moisés Navarro que ocupou o cargo durante cerca de cinco/seis anos (1361-1367) e teria dois filhos menores, em 1362, chamados José e Isaac. Teria havido um ou outro(s) filho(s) nascido(s) após a instituição dos morgados? Poder-se-ia associar D. Juda ao Moisés Navarro casado com Solouro que nos aparece no grupo destes judeus que viveram no reinado de D. Dinis? Entre estes e D. Juda há um intervalo de cerca de setenta anos. Parece-nos difícil, apesar de D. Juda ser adulto e casado quando apareceu a intervir na vida política portuguesa, quer como rabi mor, quer como tesoureiro do reino. $\mathrm{Ou}$, ainda, a um outro Moisés Navarro?

Por sua vez, Béatrice Leroy, a biógrafa da família Menir, seguiu Amador de los Ríos ao situar a deslocação dos Navarro para Portugal na sequência da matança de 1328, em Estella, e identificava um Isaac e o seu filho Moisés como tendo-se refugiado em Lisboa. Já referimos que a sua presença lhe era anterior e não conseguimos identificar estes dois judeus. De facto, os únicos Isaac que nos aparecem mencionados na documentação dionisina eram Isaac, filho de José e de Mira, e Isaac, filho de Belecide. Nenhum deles, que o saibamos, apareceria associado a um filho com o nome de Moisés.

Como vimos atrás, o rabi mor Moisés Navarro era filho de mestre José. Por outro lado, esta autora afirma que D. Juda teria nascido por volta de 1350, em Tudela. Infelizmente na descendência dos filhos do rabi mor Moisés Navarro não conhecemos nenhum Juda, apenas podemos dizer que os dois morgados, José e Isaac, viviam ainda em 1384, na turbulência

${ }^{41}$ J. Mendes dos Remédios, Os Judeus em Portugal (Coimbra: 1895 [facsimile, Lisboa: Alcalá, 2005), vol. I, 163 e nota 3. 
da revolta popular que apoiava o Mestre de Avis, como veremos. Também não conseguimos confirmar, na documentação portuguesa, a identificação de D. Juda ben Moisés Navarro ${ }^{42}$. Esta autora acrescentaria ainda uma pergunta: «Dom Jeuda ben Menir est-il leur cousin?». Não temos resposta na documentação régia para estas dúvidas.

Mas, se Juda Aben Menir era uma figura proeminente do reino no tempo de D. Fernando, continuou a sê-lo durante a curta regência da rainha viúva Leonor Teles. Acompanhava-o neste favoritismo o almoxarife da alfândega de Lisboa e rendeiro David Negro. Mas, cerca de um mês e meio após a morte do rei, com o assassinato de João Fernandes Andeiro, o fidalgo galego apontado pelo povo como amante da rainha, o poder caiu na rua. Nesta turbulência social, os judeus da cidade seriam as próximas vítimas iminentes, se não fosse o Mestre de Avis desviar a multidão de tal intento. $\mathrm{O}$ objectivo do movimento popular era roubar os judeus ricos que residiam na judiaria velha, como D. Juda, David Negro e outros. Na vozearia do povo, eles eram «traidores», «partidários da rainha» e tinham «grandes tesouros escondidos» ${ }^{43}$.

Receando a instabilidade popular, Leonor Teles abandonaria Lisboa. Na sua comitiva ia D. Juda, disfarçado de pajem, com medo da populaça amotinada, pelos «grandes agravos que fazia ao povo com os ofícios que tinha», escrevia Fernão Lopes. Daquela cidade partia para Alenquer, aqui permanecendo vários dias. Desta vila cujo senhorio detinha, a rainha seguiu para Santarém, onde se encontraria com a filha e com Juan I de Castela, seu genro. Neste concelho, a rainha ordenava

${ }^{42}$ Estas conclusões já foram conversadas, há uns anos, creio que, em Tudela, com Béatrice Leroy a quem expus as minhas dúvidas sobre esta identificação, tendo em consideração a documentação portuguesa existente. Aliás a autora manifestou a sua compreensão pela minha discordância. Lamento voltar ao assunto, mas necessitei fazêlo quando o Dr. J. del Barco, na sua investigação se deparou com um manuscrito dos finais do século XIV respeitante à transacção de uma Bíblia entre um Judas Navarro e o mestre Moisés de Leiria, rabi mor de D. João I (e a quem agradeço a possibilidade de ler e publicar o documento respeitante a dois judeus portugueses que viveram em finais de Trezentos) e me pediu para uma conferência sobre os judeus castelhanos em Portugal e nomeadamente sobre os Navarro e me associou a eles os Menir e os Leiria. Desconhecemos de onde provém este equívoco.

${ }^{43}$ L. CinTRa (ed.), Fernão LoPEs, Crónica del Rei dom João I da boa memória (Lisboa: Imprensa Nacional-Casa da Moeda, 1973), vol. I, cap. XIV, 20-31. 
aos judeus da vila que fossem receber o casal real com as suas Torah, como era costume nas entradas reais. D. Juda tinha aqui casas, teria ele encabeçado o cortejo? Mas sabemos, porque o cronista nos diz, que o facto de ele e David Negro estarem a habitar na judiaria, impediu que os castelhanos aqui se aposentassem. Tendo vagado o cargo de rabi mor de Castela, Leonor Teles pediu ao genro que provesse nele D. Juda Aben Menir. Tal não sucederia porque a rainha $\mathrm{D}$. Beatriz intercedera a favor de David Negro. Era a recompensa que a jovem rainha dava ao favorito de D. Fernando que se pusera ao seu serviço, assim que entrara em Santarém. Começava a queda de D. Juda e da rainha viúva. Sempre ao lado desta acabaria por ser implicado na conjura planeada por Leonor Teles para matar o genro, feito que deveria ter lugar em Coimbra para onde os reis, as suas comitivas e o exército castelhano se dirigiram ${ }^{44}$. Por sua vez, em Tomar, encontrava-se David Alguadix, cunhado de D. Juda, que iria meses mais tarde oferecer dinheiro a Nuno Álvares Pereira e que este recusaria ${ }^{45}$.

Seria na cidade do Mondego que os percursos de ambos seguiriam caminhos diferentes. D. Juda estava ao lado de Leonor Teles na sua tentativa de trair o genro e readquirir o poder e a autonomia do reino. David Negro denunciaria o seu correligionário e a sua rainha aos seus novos senhores, os reis de Castela. Era a queda em desgraça de Leonor e do seu favorito que seguiriam presos para Castela. Acompanhava-os Reina e outros familiares e servidores de D. Juda.

Enquanto David Negro e Juda Aben Menir acompanhavam Leonor Teles e, em certa medida, apoiariam a sua troca de correspondência com o genro, os Navarro, ou alguns deles, optavam por permanecer em Lisboa. Nesta cidade e no meio da confusão social que nela turbilhonava, Judas Navarro era recompensado pelo Mestre de Avis, cabecilha dos revoltosos. Juan I de Castela, regente e governador de Portugal, doava-lhe as casas de David Alguadix, irmão de Reina, mulher de Juda Aben Menir, contíguas às suas casas na judiaria velha de Lisboa, também ele suspeito de traição. A doação premiava um «servidor» do Mestre, mas também o apoio social e, sobretudo, financeiro

${ }^{44}$ Lopes, Crónica del Rei dom João I, vol. I, cap. XVI, LXV, LXXVI, LXXXI, LXXXIII.

${ }^{45}$ Lopes, Crónica del Rei dom João I, vol. I, cap. CXXVII. 
que aquele the poderia via a dar, uma vez que a comunidade judaica do reino e a de Lisboa tinham ficado decapitadas com o exílio do rabi mor e tesoureiro mor de D. Fernando e com a ida de David Negro, na comitiva de D. Juan I e de D. Beatriz ${ }^{46}$. Os bens móveis e de raiz deste último onde quer que se encontrassem eram doados a Nuno Álvares Pereira e os bens do ex-rabi mor em Santarém eram dados a Gonçalo Rodrigues de Abreu. A justificação era similar para ambos. David Negro e Juda Aben Menir eram tratados como traidores de Portugal e o primeiro como inimigo de Lisboa ${ }^{47}$.

Por sua vez, os bens móveis e de raiz de David Alguadix, em Setúbal e seu termo, eram doados a Fernando Álvares, vedor da casa real, porquanto este judeu não andava ao serviço de Portugal nem do seu rei, excepto a parte que devia ser vendida e pertencia à coroa porque Alguadix fora fiador de David Pulgão no arrendamento das rendas do almoxarifado de Faro ${ }^{48}$. Em 1409, o cunhado de D. Juda já tinha falecido. Sua viúva, Ester, recebia carta de quitação de D. João I, porque ela era «pobre» e ignorante dos negócios do marido que fora despenseiro de D. Fernando em nome de D. Juda Aben Menir, tendo recebido por via da sua função muitos dinheiros e prata. Tendo partido para Castela, o rei doaria os seus bens a Fernão Álvares, aio do infante D. Duarte ${ }^{49}$. Um outro membro desta família, Boino Alguadix, gibiteiro, residia em Évora no ínico do século $\mathrm{XV}^{50}$. Com D. Juda e tendo também os bens confiscados por traição estavam Judas e Moisés Nafu. Os bens e casas destes três judeus foram doados pelo Mestre de Avis a Rui Pereira e confirmados pelo rei à sua viúva, Violante Lopes ${ }^{51}$.

Mas não eram os únicos partidários de Castela que permaneceram neste reino. Guedelha Franco foi um dos que não regressou, ou pelos menos, só o faria mais tarde. Em 1389, D. João I confirmava a doação dos seus bens a Juda Navarro, apesar de posteriormente os ter doado a Rui Cravo.

${ }^{46}$ Chancelarias Portuguesas. D. João I (Lisboa: Centro de Estudos Históricos, UNL, 2004), vol. I, to I, 32 (doc. 42).

${ }^{47}$ Chancelarias Portuguesas. D. João I, 16 (doc. 12) e 45 (doc. 71), respectivamente; Lisboa, Arquivo Histórico da Cámara Municipal, Livro $3^{\circ}$ de D. João I, doc. 10.

${ }^{48}$ IAN/TT, Chancelaria de D. João I, liv. 5, fl. 17v.

${ }^{49}$ IAN/TT, Chancelaria de D. João I, liv. 5, fls. 36v-37r.

${ }^{50}$ Évora, Arquivo Diocesano, Livro de Pergaminho, cód. 67, fl. 64r.

${ }^{51}$ IAN/TT, Chancelaria de D. João I, liv. 1, fl. 94v; liv. 5, fl. 48v 
Dois anos mais tarde, o monarca ordenava que se desse a este fidalgo o valor das casas de Guedelha Franco, em Lisboa, ou outros bens de valor idêntico que este tivesse no reino ${ }^{52}$. Outro que não regressaria a Portugal porque falecera em Castela era Juda Franco, rendeiro do serviço novo dos judeus de Lisboa no ano de 1383, pelo que as suas casas em Lisboa seriam doadas a Fernão Álvares, talvez, o irmão de Nuno Álvares Pereira ${ }^{53}$.

Nuno Álvares Pereira que recebera os bens de David Negro, entre os quais sete casas na judiaria grande de Lisboa, legaria para memória futura um repertório da sua traição com as respectivas testemunhas. Ao contrário de D. Juda, o almoxarife de D. Fernando regressara a Portugal no exército invasor, estivera presente no cerco de Lisboa e, mais tarde, em Aljubarrota, de onde fugiria acompanhando o monarca derrotado a caminho de Badajoz. Por esse memorando ficámos a saber que o novo rabi mor de Castela, solicitara a D. Juan I de Castela no cerco de Lisboa que lhe desse os bens de José Navarro, provavelmente, um dos dois filhos do rabi mor Moisés Navarro, tendo-os obtido por carta régia do monarca castelhano. A este artigo do repertório, o condestável, nomeava como testemunhas do acto José e Isaac Navarro, seu irmão, assim como Judas Franco e o seu irmão Isaac Franco, José Gabay, Lázaro Latão e José Aliot, ferreiro, morador em Santarém.

David Negro tornara-se o braço do rei de Castela e, durante o cerco e a destruição da armada que vinha do Porto para libertar Lisboa, fora ele quem estivera nos barcos portugueses a fazer o levantamento dos bens que deveriam ser confiscados e a ordenar a prisão dos marinheiros e soldados portugueses, em Julho-Agosto de 1384. Tudo isto fora testemunhado por Judas Franco e pelo seu irmão, assim como por alguns cavaleiros e escudeiros presos. Aqui, alguns destes seriam trocados pela libertação da mulher, Cinfa, e de outros familiares de David Negro. Verifica-se que os Franco e José Gabay eram servidores do almoxarife de Lisboa. Aliás, Juda Franco aparecia identificado como procurador daquele ${ }^{54}$.

${ }^{52}$ IAN/TT, Chancelaria de D. João I, liv. 5, fl. 16r.

${ }^{53}$ IAN/TT, Chancelaria de D. João I, liv. 5, fl. 21v

${ }^{54}$ IAN/TT, Corporações Religiosas, Mosteiro do Carmo de Lisboa, liv. 18, fls. 1v7v, 13v-16v, 18v, 19v; P. de Azevedo, «Culpas de David Negro», Archivo Histórico Portuguez I (1903), 53-57: 55-56; Chancelarias Portuguesas. D. Duarte (Lisboa: Centro de Estudos Históricos, UNL, 1998), vol. I, t. I, 13 (doc. 17). 
Não é fácil identificar estes Navarro nem em que partido se posicionavam, se pró-Portugal, se pró-Castela. Sabemos que, perante a fome e a escassez de alimentos durante o cerco de Lisboa, os judeus e as prostitutas foram expulsos da cidade, segundo nos conta Fernão Lopes, os quais foram, no início, bem recebidos no arraial castelhano ${ }^{55}$. Podemos deduzir que o José Navarro que teve os seus bens confiscados pelo rei de Castela a favor de David Negro, estivesse em Lisboa, ao lado do Mestre de Avis. Mas seria ele o José, irmão de Isaac, testemunhas deste confisco? E quando ocorreu esse confisco? Durante o cerco de Lisboa? Ou mais tarde, porventura em Castela? E seriam estes, José e Isaac, filhos do rabi mor Moisés Navarro? Supomos que sim, pois a fortuna destes não era despicienda e, por isso, facilmente cobiçada por eventuais inimigos, apesar de correligionários. Não esqueçamos que um Navarro, Moisés, interrompeu a «dinastia» dos Negro / Ibn Yahia no cargo de rabis mores do reino e receberia bens do rabi Guedelha Negro em Lisboa que lhe foram doados por D. Pedro I.

Mas nem todos os Navarro teriam apoiado o Mestre de Avis que deu os bens de José Navarro e José Pardo a João Rodrigues de Sá, porquanto andavam ao serviço de Castela ${ }^{56}$. Obviamente a homonímia frequente impede-nos de saber quem é este José Navarro, traidor ou pseudo-traidor, pois sabemos que o Mestre entregava os bens a quem lhos pedia sem se preocupar em certificar-se se o seguiam ou não, corrigindo o acto posteriormente.

Alguns anos mais tarde, o rei D. João I confirmava a doação feita a Judas Navarro dos bens de Guedelha Franco que permanecia em Castela ${ }^{57}$. Este último fora rendeiro dos panos na cidade de Lisboa no tempo de D. Fernando e ficara com uma dívida à coroa que seria doada pelo monarca ao cavaleiro Rui $\mathrm{Cravo}^{58}$.

Entretanto, os Navarro assumiam-se como rendeiros do rei. Em 1395, um Jacob Navarro era rendeiro dos serviços real e novo dos judeus de Setúbal e agravava-se ao monarca sobre o prejuízo que ambos sofriam por causa da constante mobilidade de alguns judeus, o que impedia que o rendeiro do

\footnotetext{
${ }^{55}$ LoPes, Crónica del Rei dom João I, vol. I, cap. CXLVIII.

${ }^{56}$ Chancelarias Portuguesas. D. João I, 86 (doc. 174).

${ }^{57}$ IAN/TT, Chancelaria de D. João I, liv. V, fl. 16r.

${ }^{58}$ IAN/TT, Chancelaria de D. João I, liv. 5, fl. 15v.
} 
local pudesse recolher o pagamento dos impostos. E referia alguns nomes como Bento do Campo, Jacob Maçoude, Salomão Daniel e outros judeus que tinham ido morar para outras paragens. Uns anos mais tarde, o mesmo judeu ou um seu homónimo, ganhava a renda do serviço real de Lisboa ${ }^{59}$.

Num instrumento de venda de uma Bíblia, em vinte e quatro volumes, por um Judas Navarro, filho de um Moisés Navarro, a mestre Moisés de Leiria, cirurgião de D. João I e rabi mor, no ano de 1396, somos confrontados com um novo membro desta família alargada, assim como com um Salomão Navarro, tabelião do rei na comuna de Lisboa ${ }^{60}$. Não cremos que este Moisés Navarro fosse o rabi mor de D. Pedro I, pois, parece-nos que ele já não seria vivo no tempo de D. Fernando, quando o rei doou umas casas a D. Juda Aben Menir, na rua do Chancudo, que Moisés Navarro tinha trazido aforadas à coroa. No mesmo raciocínio que fizemos a respeito da possível ligação familiar de Juda Aben Menir a Moisés Navarro, devemos fazer em relação a este Juda Navarro. Que o saibamos o rabi mor de D. Pedro I não teve nenhum filho de nome Juda. Mas não podemos garantir que o não tivesse tido, posteriormente à criação dos dois morgados. $\mathrm{O}$ grande problema para estas identificações de parentesco é a existência de homónimos contemporâneos. No entanto, sabemos que no clã original dos Navarro em Portugal outros ramos desta família alargada usavam o nome de Moisés e de Juda, como vimos. Porventura estes Moisés e Juda Navarro pertenceriam a um deles?

Também nada nos permite afirmar que mestre Moisés de Leiria fosse um Navarro, ao contrário do que escreveu Amador de los Ríos que o identificava como filho de Moisés Navarro, rabi mor de D. Pedro I. Seguindo este raciocínio, Moisés de Leiria teria sido irmão de Juda Aben Menir... Em 1391, D. João I doava a mestre Moisés, seu físico, um pardieiro em Leiria que servira de cavalariça no tempo da rainha D. Isabel, mulher de D. Dinis, e agora se encontrava em ruínas o qual este judeu trazia aforado à coroa ${ }^{61}$. No ano seguinte, apresentava ao rei um agravo da comuna de Évora que lhe fora presente pelo rabi Vivas Lubel. Queixava-se a comu-

${ }^{59}$ IAN/TT, Gavetas da Torre do Tombo, Gaveta 10, m. 12, doc. 17.

${ }^{60}$ Paris, BnF, MS. héb. 21, in J. DEL BARCO, Manuscrits en caractères hébreux conservés dans les bibliothèques de France. Catalogues. IV. Manuscrits de la Bible hébraïque. Hébreu 1 à 32 (Turnhout: Brepols, 2011), 124-130. Vide uma transcripção moderna em apéndice d'este artigo.

${ }^{61}$ IAN/TT, Chancelaria de D. João I, liv. 2, fl. 62v; Estremadura, liv. 2, fls. 67r-v. 
nidade de que os oficiais da justiça penhoravam a comuna nos bens das sinagogas, incluindo as Torah e as pratas, e requeria que as penhoras que houvesse fossem feitas nas rendas ${ }^{62}$.

No mesmo ano de 1392, este rabi mor apresentava à confirmação do soberano a bula de Bonifácio IX, que, por sua vez, confirmava bulas anteriores onde se manifestava a protecção da Santa Sé aos judeus que residissem na cristandade. É provável que este pedido de mestre Moisés respondesse à necessidade de prevenir quaisquer levantamentos ou abusos contra a população judaica residente no reino e não a quaisquer perseguições aos judeus portugueses, como pretendia Amador de los Rios ${ }^{63}$.

Se ocorreram algumas perturbações que pudessem ter levado à partida de alguns dos judeus castelhanos fugidos às perseguições e aos baptismos forçados, como, de facto, aconteceu com a ida de judeus portugueses e castelhanos para a Sicília, elas tiveram como base o facto de alguns os acusarem de terem recebido o baptismo e, em Portugal, terem voltado ao judaísmo, pelo que o rei lhes confiscava os bens e os mandava prender e julgar. A comuna de Lisboa onde a maioria deles residia pedia clemência a D. João I e que este atendesse ao facto de o baptismo não ter obedecido às regras da Igreja e que o mesmo fora obtido por medo e por sobrevivência. Esta circunstância seria usada pelo rei como preâmbulo à legislação onde ordenava que nenhum destes fosse preso ou perdesse os bens que possuía, apesar de ser fama que tinham sido cristãos em Castela, excepto se houvesse feito a correr na justiça com testemunhas nomeadas que comprovassem que eles tinham recebido o baptismo como mandava a Santa Igreja e o direito o exigia ${ }^{64}$.

Em 1402, já não era rabi mor do reino mas sim o seu sucessor D. Juda Cohen. No entanto, ainda era vivo pois D. João I consultá-lo-ia a propósito das jurisdições do arrabiado mor que estavam a ser abusivamente extrapoladas por Juda Cohen com grandes agravos dos rabis e outros oficiais das comunas do reino. Mais uma vez, na ordenação, o rei apenas identificava o ex-rabi mor por mestre Moisés, enquanto naquela ele era

${ }^{62}$ IAN/TT, Chancelaria de D. João II, liv. 21, fls. 158v-159r.

${ }^{63}$ Ordenações Afonsinas (Lisboa: Fundação Calouste Gulbenkian, 1984), vol. II, 514520 (tit. LXXXXIIII); AMADOR DE LOS Ríos, Historia social, política y religiosa, 512-516.

${ }^{64}$ Ordenações Afonsinas, vol. II, 457-461 (tit. LXXVII). 
também seu físico ${ }^{65}$. Infelizmente, em nenhum dos documentos que chegaram até nós mestre Moisés nos aparece identificado por outro apelido que o «de Leiria». Este tanto podia ser o apelido da família justificado pelo local de origem ou de residência da mesma.

Um Judas Navarro era designado «servidor de D. João I», muito provavelmente aquele que recebeu como recompensa as casas de David Alguadixe, como já referimos, e talvez o mesmo que comprou uma Bíblia que vendeu a mestre Moisés de Leiria. Faria uma carreira de oficial da comuna de Lisboa, onde ocupou a escrivaninha da câmara. Faleceria cerca de $1443^{66}$. Outro Navarro, neste caso, Salomão, foi tabelião do rei na comuna, como referimos acima.

Na judiaria velha residiam, em 1435, Guedelha Navarro o qual era vizinho de Gabriel Aben Crespo ${ }^{67}$, sendo ambos primos entre si. Por documento de 1457, Guedelha Navarro, neto do rabi mor Moisés Navarro, apresentava a $\mathrm{D}$. Afonso $\mathrm{V}$ a confirmação do morgado na sua pessoa, uma vez que apenas seu pai, Isaac, tinha tido varão. O seu tio, José, tivera uma filha, Lediça. Esta por sua vez tivera um filho Gabriel ben Crespo que acabaria por ter confirmado em si o morgado que coubera a José Navarro, seu avô ${ }^{68}$. Guedelha, nome pouco vulgar entre os Navarro, devia ser o filho mais novo vivo de Isaac, uma vez que havia uma distância de cerca de noventa anos entre a instituição do morgado e este neto de Moisés Navarro. Obviamente que o pai não teria sobrevivido até meados do século $\mathrm{XV}$, o que nos faz supor que um ou mais filhos de Isaac lhe tenham sucedido e, entretanto, falecido sem descendência. Também o nome Guedelha, vulgar entre os Negro, nos leva a pensar que a mulher ou uma das mulheres de Isaac e mãe de Guedelha pertencesse a esta família. Ou seja, seria o favor régio que manteria o morgado nos descendentes de Isaac e de José, apesar de Lediça não ter tido como marido um Navarro mas um Aben Crespo.

Curiosamente, as duas filhas de Gabriel Aben Crespo, Anegarxa e Amada, casariam com os dois filhos de David Negro, Judas e José, res-

\footnotetext{
${ }^{65}$ Ordenações Afonsinas, vol. II, 476 (tit. LXXXI).

${ }^{66}$ IAN/TT, Chancelaria de D. João I, liv. 1, fl. 6v; Chancelaria de D. Afonso V, liv. 27, fl. 119 r.

${ }^{67}$ Chancelarias Portuguesas. D. Duarte, vol. I, t. I, 414 (doc. 675).

${ }^{68}$ IAN/TT, Estremadura, liv. 4, fls. 259v-261v; liv. 8, fls. 282r-283r.
} 


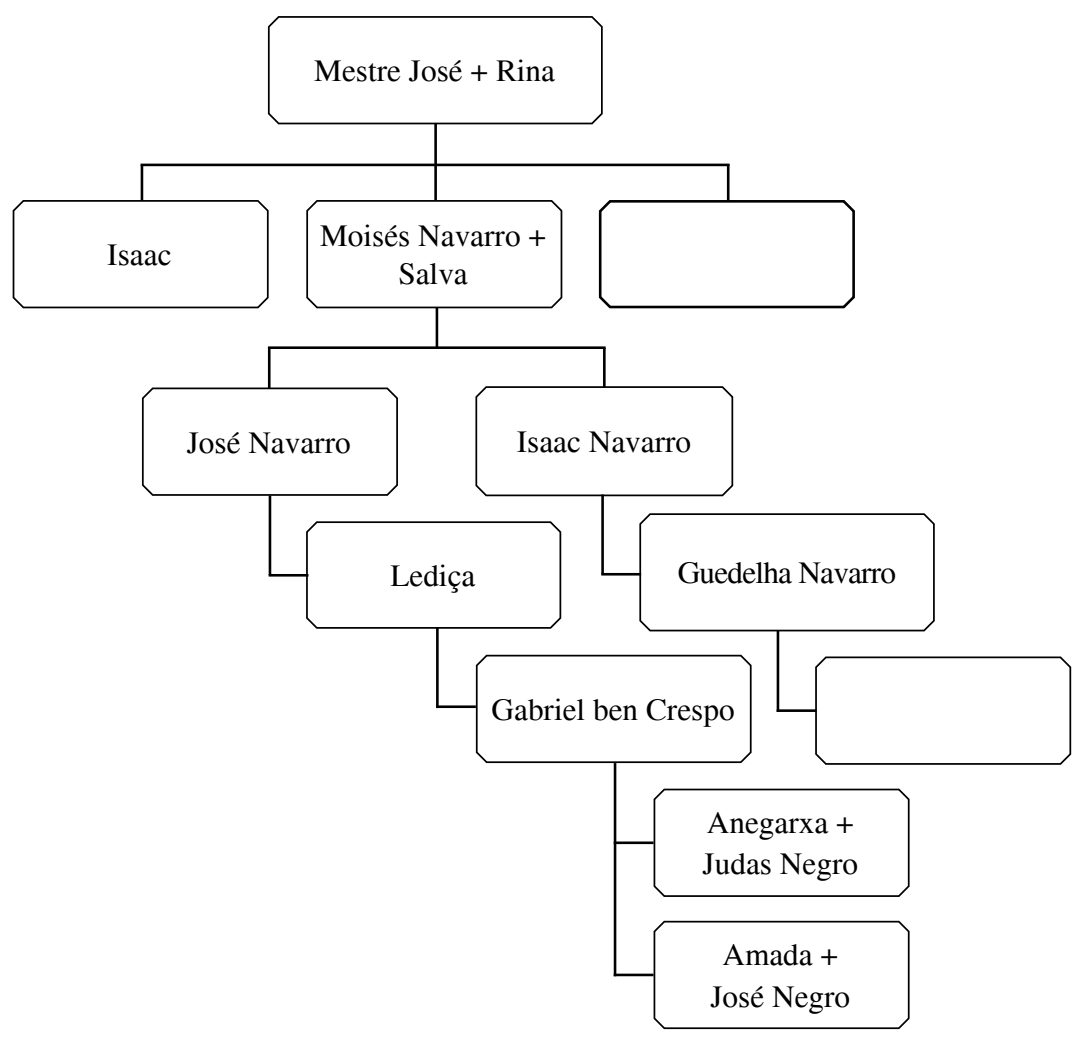

pectivamente $^{69}$, provavelmente, irmão do rabi mor Guedelha Negro e neto do David Negro, almoxarife de D. Fernando e rabi mor de Castela. Ou seja, os Aben Crespo e os Negro ficavam ligados aos Navarro. Em 1447, Gabriel dera ao rei as casas próprias que estavam na zona cristã de Lisboa, em Valverde, e, em troca, este libertara de qualquer foro as casas em que eles viviam junto ao poço da Foteia, no interior da judiaria grande. Como testemunhas deste acto, estiveram José Penafiel e José Haim, sendo tabelião da comuna um Abraão Manuel.

Um outro Moisés Navarro, mercador, ganhava, em 1459, uma carta de privilégio de $\mathrm{D}$. Afonso $\mathrm{V}$ graças à intervenção de $\mathrm{D}$. Filipa, prima

${ }^{69}$ IAN/TT, Chancelaria de D. Afonso V, liv. 35, fls. 5-7; Direitos Reais, liv. 1, fls. 56v-60v; Estremadura, liv. 5, fls. 112v-116v. 
do rei e certamente a filha do regente D. Pedro, irmã da rainha D. Isabel e tia do príncipe herdeiro. Com esta carta régia, podia o mercador judeu deslocar-se em mula com sela e freio, andar com armas, pousar em estalagens cristãs, andar sem sinal pelos caminhos e durante os três primeiros dias em que permanecesse num determinado local ${ }^{70}$. Em 1485, um Moisés Navarro era um dos vereadores da câmara da comuna de Lisboa ${ }^{71}$. Este ou um seu homónimo e o filho Eleázar Navarro, ambos mercadores, mantinham negócios com a Guiné. No entanto, teriam utilizado certas mercadorias defesas e dinheiro neste comércio pelo que entregariam, por ordem de D. João II, mil dobras de ouro da Guiné ao duque D. Diogo, quantia pela qual o monarca lhes perdoava a infracção cometida ${ }^{72}$.

Outros Navarro residiam em Évora, cidade que se tornava tal como Lisboa um sítio onde a corte de Avis residia. Ainda no final do século XIV, era rabi da comuna de Évora Juda Navarro que tinha como parceiro Moisés Caldeirão ${ }^{73}$. No início do século XV, os Navarro deviam ser uma família com uma certa preponderância pois davam o nome a uma rua da judiaria nova: rua de José Navarro. Este era rabi da comuna no ano de 1429. Na mesma rua residia também um José Barcelonim ${ }^{74}$. Em 1461, eram rabis o mercador Isaac Navarro e José Pinto, especieiro ${ }^{75}$. No ano de 1469, Isaac Navarro era rabi juntamente com Isaac Zaboca, enquanto outros Navarro, Juda e Faram, eram vereadores e homens bons da comuna. Eles faziam parte dos oficiais desta que assinavam um compromisso com os representantes dos mesteirais sobre a repartição das despesas da comuna de modo a que os mais pobres não se sentissem agravados pelos poderosos e ricos ${ }^{76}$. Em 1472, vários membros da família Navarro tinham

${ }^{70}$ IAN/TT, Chancelaria de D. Afonso V, liv. 36, fl. 214v.

${ }^{71}$ J. A. Freitas de Oliveira, «A colecção de pergaminhos do Arquivo Municipal de Almada. Transcrição e apontamento introdutório», Anais de Almada. Revista Cultural 7-8 (2006), 47-79: 66-69. Este documento único, infelizmente, é uma acta da câmara de vereação da comuna de Lisboa.

${ }^{72}$ IAN/TT, Chancelaria de D. João II, liv. 3, fl. 74r.

${ }^{73}$ IAN/TT, Chancelaria de D. João II, liv. 21, fl. 160r.

${ }^{74}$ Évora, Arquivo Distrital, Fundo da Santa Casa da Misericórdia, Albergarias $e$ Hospitais do Corpo de Deus da Sé, cód. 63, fls. 72v-73r.

${ }^{75}$ IAN/TT, Chancelaria de D. João II, liv. 21, fl. 168r.

${ }^{76}$ IAN/TT, Chancelaria de D. Afonso V, liv. 36, fls 219r-v. 
o nome inscrito no livro da câmara de vereação da comuna de Évora. Eram eles: Isaac Navarro, o velho, Isaac Navarro, o moço, e José Navarro. Com eles, estavam os rabis Salomão de Illescas e mestre Moisés Tobi, e os vereadores Moisés Toledano e mestre Judas Toledano ${ }^{77}$.

Neste mesmo ano de 1472 , o príncipe D. João intercedia junto do rei a favor do rabi Moisés Navarro, doutor da Lei na comuna de Évora, porquanto ordenara que ele ensinasse gratuitamente o que o dito rabi não cumprira, tendo recebido uma tença da comuna e auferido de uma seda na sinagoga e outras dignidades. O monarca perdoar-lhe-ia e ordenava-lhe que entregasse metade da tença aceite ${ }^{78}$. Também neste ano, um José Navarro era nomeado tabelião da comuna em substituição de Judas Barrocas, acusado de cometer erros no desempenho do seu cargo $^{79}$. Numa carta de perdão dada pelos familiares de Abraão Alufo, assassinado por Rui Fernandes, criado de Rui Dias Lobo, encontramos a referência ao ourives Abraão Navarro, tutor dos filhos da vítima ${ }^{80}$. Contemporâneo destes Navarro era um Salomão que, contra as ordenações do reino, exercera um ofício da competência exclusiva de cristãos pelo que fora preso na prisão da corte e fora condenado a cumprir três anos de degredo em Ceuta, acabando por ser perdoado ${ }^{81}$.

A convivência entre cristãos e judeus permitira que Isaac Navarro, o moço, residente em Évora e Moisés Toledano fizessem viagem em conjunto com um grupo de escudeiros de Castela para Portugal. No entanto, as relações entre um dos escudeiros de nome Diogo Velho e Moisés Toledano deterioraram-se, acabando aquele por ferir este. De tal acto seria acusado às justiças portuguesas por Isaac Navarro ${ }^{82}$.

O rabi Ezra Navarro recebia, em 1480, carta de privilégio para poder deslocar-se em mula. No mesmo ano, mestre Moisés Navarro obtinha carta para exercer a profissão de físico nesta cidade alentejana ${ }^{83}$.

\footnotetext{
${ }^{77}$ IAN/TT, Chancelaria de D. Afonso $V$, liv. 29, fl. 27v.

${ }^{78}$ IAN/TT, Chancelaria de D. Afonso $V$, liv. 29, fl. 38v.

${ }^{79}$ IAN/TT, Chancelaria de D. Afonso V, liv. 29, fl. 86r.

${ }^{80}$ IAN/TT, Chancelaria de D. Afonso $V$, liv. 17, fl. 76v.

${ }^{81}$ IAN/TT, Chancelaria de D. Afonso $V$, liv. 17, fl. 83r.

${ }^{82}$ IAN/TT, Chancelaria de D. Afonso V, liv. 17, fl. 75v.

${ }^{83}$ IAN/TT, Chancelaria de D. Afonso $V$, liv. 32, fls. 142v e 121r.
} 
Em 1490, um Samuel Navarro, criado de Toledano, fora acusado por este de roubo, pelo que fora preso na cadeia da judiaria de Évora. Em sua defesa alegava a falsidade da acusação, a qual fora motivada porque se recusara a partir para Castela como Toledano pretendia, pois sabia que o seu criado o queria denunciar às justiças ${ }^{84}$.

Já no final da permanência da minoria no reino, residia em Évora um Eléazar Navarro que pagara 50000 reais ao rei, verba que nos é conhecida pela carta de quitação dada por D. Manuel a João Álvares Rangel, em $1496^{85}$.

Outro Samuel Navarro, ourives, natural de Setúbal reclamava das justiças o ouro e a prata que lhe tinham sido confiscados porque alguém denunciara que as mercadorias que ele vendia tinham sido roubadas, quando ele era judeu de «boa fama» ${ }^{86}$.

Outros residiam na Guarda, como Moisés Navarro, mercador que, em 1454, recebia a carta régia que lhe permitia fazer qualquer contrato no reino, e Abraão Navarro, vizinho de Salomão Mofejo e de Moisés Maçoz. Nos finais da década de 1480, a viúva de David Navarro herdava uma casa cujo acesso se fazia por uma escada de pedra e avizinhava com a sinagoga. Noutros concelhos da Beira, viviam outros Navarro como um Abraão Navarro, alfaiate em Castelo Branco, ou Samuel, Isaac e Jacob Navarro, estes moradores em Gouveia ${ }^{87}$. Ou ainda mestre José Navarro que exercia cirurgia em Abrantes ${ }^{88}$.

Mas havia Navarro que residiam também em Torres Novas. Nos finais do século XV, os Navarro deste concelho cruzavam-se com os Zarco e os Folega ${ }^{89}$. Um deles, o mercador Moisés Navarro obtinha permissão do soberano para se deslocar em mula e noutra carta de privilégio era designado também servidor do rei ${ }^{90}$. Este ou um seu homónimo, também

\footnotetext{
${ }^{84}$ IAN/TT, Chancelaria de D. João II, liv. 13, fls. 141v-142r.

${ }^{85}$ IAN/TT, Extras, fl. 1v.

${ }^{86}$ IAN/TT, Chancelaria de D. João II, liv. 3, fls. 44r-v.

${ }^{87}$ IAN/TT, Chancelaria de D. Afonso $V$, liv. 16, fl. 7r; liv. 15, fls 158v, 165r; liv. 31, fl. 25r; Beira,liv. 1, fls. 143r-v e liv. 2, fls. 202r-203r.

${ }^{88}$ IAN/TT, Chancelaria de D. João II, liv. 8, fl. 73r.

${ }^{89}$ IAN/TT, Chancelaria de D. João II, liv. 11, fls. 23r-v.

${ }^{90}$ IAN/TT, Chancelaria de D. Afonso V, liv. 26, fl. 63v; Chancelaria de D. João II, liv. 24, fl. 136r.
} 
mercador, negociava em azeite, tendo sido alvo de roubo por dois correligionários seus, Abraão Franco e Isaac Gualite ${ }^{91}$. Mas teriam alguma relação com os Navarro de Lisboa? E estes com os de Évora?

Desconhecemos a relação familiar, se, porventura, existia, entre os diversos Navarro dispersos pelo reino. Verificamos que eles pertenceram a uma elite de famílias judaicas residentes em Lisboa e Évora, mas não cortesãs. Durante o século XV, assistimos à recuperação do poder por parte dos Negro e à ascensão de outras famílias como os Abravanel, os Latam, os Palaçano.

O século XVI assistiria à permanência de algumas destas famílias em Portugal -o apelido Navarro ainda hoje se conserva- e à emigração de outras para Itália, onde se assumiriam como judeus ${ }^{92}$. Deixemos agora os Navarro e vejamos uma outra família, pertencente à elite judaica, os Abravanel.

\subsection{Os Abravanel}

Esta família entrou em Portugal, tal como muitas outras, na sequência dos movimentos antijudaicos que Castela conheceu no tempo de Enrique II e, mais tarde, com as pregações inflamadas de arcediago de Écija e de frei Vicente Ferrer. Sevilla foi uma cidade onde os movimentos xenófobos se fizeram sentir, tendo como consequência algumas conversões forçadas para além da emigração. Tal aconteceu com Samuel Abravanel, o velho, filho de Juda, almoxarife de Sevilla no tempo de Juan I, que fora convertido à força ao cristianismo com o nome de Juan Sánchez de Sevilla, por volta de $1391^{93}$.

Entre os recém-vindos, fugitivos às perseguições motivadas pela xenofobia e a intolerância religiosa de alguns cristãos, encontramos os Abravanel que se fixaram no início, em Évora. Em finais do século XIV,

${ }^{91}$ IAN/TT, Chancelaria de D. João II, liv. 24, fls. 111r-v.

${ }^{92}$ P. C. Ioly Zorattini, Processi del S. Uffizio di Venezia contro Ebrei e Giudaizzanti (1571-1580) (Firenze: Leo S. Olschki Editore, 1985), 79.

${ }^{93}$ Kayserling, História dos Judeus em Portugal, 63, nota 33; AmAdOR DE Los Ríos, Historia social, política y religiosa, 318, nota 1; B. NETANYAHU, Don Isaac Abravanel, statesman and philosopher (Philadelphia: JPS, 197233), 3-9 e 266-267, notas 12 e 14; Y. BAER, A History of the Jews in Christian Spain (Philadelphia: JPS, 1966), vol. I, 378 e vol. II, 93. 
um Isaac Abravanel residia nesta cidade e aforava, em 1400, umas casas pertencentes à albergaria de $\mathrm{S}$. Julião na rua direita da judiaria, na presença do bispo e dos confrades. Na discussão sobre o valor do foro, alegava a albergaria que as casas eram suas e estavam mal aforadas a Abraão Sarcoito. Este largou-as a favor de Isaac Abravanel que se comprometeu a pagar por elas 3 dobras de ouro ${ }^{94}$.

Desconhecemos qual a relação familiar deste Isaac com Samuel Abravanel que foi baptizado em Sevilla. Ele pertenceu à primeira leva de imigrantes desta importante família sevilhana e desconhecemos se recebeu as águas do baptismo como Samuel que, segundo diversos autores, teria vindo para Portugal por volta de 1414. Em 1400, era um adulto com bens suficientes para aforar a casa à albergaria de S. Julião e indemnizar o correligionário para largar a casa que trazia. Cedo, entraram em contacto com a corte, como seus credores. Um Abravanel, residente em Lisboa, em 1437, emprestara 52000 reais ao infante D. Fernando e, por isso, o conhecemos, pois o seu nome constava do testamento do filho mais novo de D. João I quando partiu para a desastrosa tentativa de conquista da cidade de Tânger ${ }^{95}$. Infelizmente não o identificou melhor, pelo que nos fica a dúvida se teria sido este Isaac, residente em Évora, dadas as relações do infante com a ordem de Avis, o credor do infante ou Juda Abravanel, o conhecido filho de Samuel e pai do famoso Isaac Abravanel. Consta que o converso Juan Sánchez veio para Portugal em 1414. Dele não encontrámos qualquer vestígio que o associasse aos Abravanéis judeus, embora saibamos a benevolência de D. João I para com os conversos castelhanos que regressaram em Portugal ao judaísmo.

Um Judas Bravane, certamente Bravanel, sem profissão definida, aparece-nos identificado em 1441 como residindo em Lisboa, o que nos permite associá-lo ao filho de Samuel. Ao mesmo ano e, também sem menção a uma profissão, surge-nos $Y a$ e José Bravane ${ }^{96}$.

${ }^{94}$ Évora, Arquivo Distrital, Fundo da Santa Casa da Misericórdia, Albergarias e Hospitais do Corpo de Deus da Sé, cód. 63, fl. 1r.

${ }^{95}$ IAN/TT, Reis, liv. 1, fls. 85r-92r; As Gavetas da Torre do Tombo VI (Lisboa: Centro de Estudos Históricos Ultramarinos, 1967), 186-202: 194.

${ }^{96}$ IAN/TT, Chancelaria de D. Afonso $V$, liv. 2, fl. 76v. 
Também mal identificado está o Abravanel que, com Catalão, seria o conselheiro económico e financeiro de D. Afonso V, cerca de 1453. Os conselhos iniciavam-se por uma resenha das emissões monetárias nacionais e dos circuitos dos metais nobres, ouro e prata, assim como a tradicional fuga destes para Castela, o que comprovava um profundo conhecimento da evolução do numerário nacional desde os finais do século XIV, a sua desvalorização e revalorização. Propunham remédios, defendendo a cunhagem de moedas boas, mas chamando a atenção para o facto de a moeda portuguesa possuir melhor lei do que a castelhana pelo que seria forçoso $o$ seu contrabando para o reino vizinho onde acabaria fundida, e consequentemente por esvaziar os cofres do tesouro régio. Desaconselhavam as emissões abundantes das pequenas moedas de cobre ou de bolhão, porque prejudiciais à economia. Apresentavam sugestões para os ourives não venderem metais preciosos a estrangeiros, nem que ourives estrangeiros trabalhassem o ouro e a prata em Portugal. Desaconselhavam o comércio de genoveses e outros italianos no reino, pois o comércio devia pertencer aos portugueses, e rematavam dizendo que um povo rico faria um reino rico ${ }^{97}$.

Curiosamente, estes dois judeus ao oporem-se ao comércio italiano estavam a defender os seus interesses e os dos seus correligionários, porque se sentiam naturais do reino, apesar da origem das famílias ser castelhana e catalã. Se desconhecemos quem era o Catalão, embora saibamos que uma família com este apelido residia na judiaria nova das taracenas desde finais do século XIV, é possível que o Abravanel fosse Juda, dado o papel que desempenhou durante o reinado de $\mathrm{D}$. Afonso $\mathrm{V}$.

No início do governo deste monarca, ainda na década de 1440, durante a regência do infante D. Pedro, um Juda Abravanel, mercador, era rendeiro e tratador das moradias do rei entre 1446-1450 e, também, rendeiro da sisa do haver do peso de Lisboa. Nestas rendas tivera a parceria de outros judeus e cristãos, nomeadamente, os italianos Leonardo e Marco Lomelino. Aparecia mencionado como servidor do rei. Era contemporâneo de um José Abravanel, residente em Lisboa, na judiaria grande, talvez o José Abravanel, o velho, casado com Luna, referido num aforamento em 1476. Provavelmente o mesmo José Abravanel, o velho, que comprou

${ }^{97}$ A. C. TeixeIRa de ARAgão, Descrição geral e histórica das moedas cunhadas em nome dos reis, regentes e governadores de Portugal (Porto: Livraria Fernando Machado, $1964^{2}$ ), vol. I, 374-381. 
umas casas na judiaria grande, em 1449, por 40 escudos de ouro portugueses e as doara à confraria dos judeus para serem arrendadas e a sua receita utilizada no apoio a judeus pobres e no resgate de judeus cativos, como aconteceria na conquista de Arzila. Pela confirmação da doação das casas, em 1472, sabemos que estas confrontavam com casas de Isaac Abet, com casas da confraria grande e com casas de Samuel Abravanel. Justificavam a doação porque José Abravanel e sua mulher Luna eram já velhos «e tinham assaz com que viver e para deixar aos filhos depois de suas mortes ${ }^{98}$. As últimas menções a Juda e a José, o velho, pertencem a meados da década de 1470, respectivamente 1471 e 1476.

Por sua vez, Ya Abravanel, surge-nos mencionado na documentação régia como mercador e, depois, tratador das moradias do duque D. Diogo, cunhado de D. João II, entre 1462 e 1491, ano em que já nos aparece indicado como tendo falecido, pelo que pensamos ser $\mathrm{Ya}$ Abravanel, o velho ${ }^{99}$. De facto, entre 1472 e 1479, a documentação régia indicava um $\mathrm{Ya}$ Abravanel, o moço, que recebia do rei carta de privilégio e contribuía para a guerra que $\mathrm{D}$. Afonso $\mathrm{V}$ levava a cabo pelo trono de Castela ${ }^{100}$.

No nosso trabalho de doutoramento ${ }^{101}$ pusemos como hipótese que Juda, José e $Y a$, a geração mais antiga no reino, fossem irmãos, mas temos dúvidas tanto mais que agora conhecemos um outro membro da família que veio para Portugal naquele final de Trezentos. Seria aquele Isaac Abravanel irmão de Samuel? Ou irmão de Juda? Ou um outro parente? E $Y a$ seria o Yacob mencionado nas genealogias judaicas desta família?

$\mathrm{O}$ crédito que estes judeus fizeram à casa de Avis, nomeadamente, a D. Afonso $\mathrm{V}$ e aos seus parentes, os duques de Bragança e de Viseu/ Beja, tornaram-nos figuras preponderantes na corte. Eles eram mercadores, rendeiros e banqueiros do rei e da família real. Emprestavam dinheiro

${ }^{98}$ IAN/TT, Chancelaria de D. Afonso $V$, liv. 3, fls. 86v-87r; liv. 2, fl. 76v; liv. 13, fl. 35v; liv. 16, fl. 35r; liv. 29, fls. 63r-64v; Estremadura, liv. 8, fls. 299r-300r; liv. 4, fls. 67r-69r e 205r-206v; Extras, fls. 69v-70r e 119v-120r; Direitos Reais, liv. 1, fls. 66r-68r.

${ }^{99}$ IAN/TT, Chancelaria de D. Afonso V, liv. 1, fl. 16v; liv. 32, fl. 38v; Chancelaria de D. João II, liv. 7, fl. 25r; Estremadura, liv. 11, fls. 31v-34r; liv. 10, fls. 134r-136v; Corpo Cronológico, Parte $1^{\mathrm{a}}$, m. $10, \mathrm{n}^{\mathrm{o}} 165$.

${ }^{100}$ IAN/TT, Chancelaria de D. Afonso V, liv. 33, fl. 182v.

101 Tavares, Os Judeus em Portugal no século xV, 227-231. 
que, na maior parte dos casos, devia ser pago em privilégios e favores reais. Pela carta de quitação dada ao infante D. Fernando, irmão do rei, em 1462, pelo dinheiro que D. Afonso V mandara entregar-lhe em Roma, sabemos que parte dos 1.500 ducados era devida a $Y a$ Abravanel. Neste mesmo ano, este judeu recebia do rei, por intermédio do tesoureiro da moeda de Lisboa, 200000 reais $^{102}$. Em 1480, D. Afonso V permitia a um Ya Abravanel, seu servidor, exportar as suas mercadorias por mar em nome de cristãos, dizimando-as em seu nome no retorno ${ }^{103}$. Entendia-se esta protecção pelo facto de os corsários castelhanos não devolverem as mercadorias tomadas em nome de judeus, o que equivalia a uma dupla perda: do mercador judeu e do rei.

Entre 1467 e 1469, Juda Abravanel deteve a renda do quarto dos ingleses, pelo que seria obrigado a entregar na Flandres 3000 coroas de 4 soldos a coroa a Vicente Gil, feitor do rei. Esta entrega de dinheiro funcionou como um empréstimo ao monarca, pelo que este deu a Juda a carta de quitação em como recebera esta quantia ${ }^{104}$.

Em 1466, Samuel Abravanel, mercador e servidor do rei, aforava umas casas régias, constituídas por sótão, sobrados e uma tenda pequena na ferraria da judiaria grande, por 500 reais brancos ${ }^{105}$. Mais tarde, o foro das casas em que habitava, assim como as de outros judeus de Lisboa, constituía parte da tença que D. João II doaria a Lopo de Figueiredo, seu escudeiro ${ }^{106}$. Samuel faleceu antes de Outubro de 1487, tendo tido conhecimento, como toda a sua família, do apoio pessoal e monetário que Isaac Abravanel dava ao duque de Viseu. Casara com Benvinda e tivera, pelo menos, dois filhos, José e Jacob que fugiriam com o tio para Castela. O casal seria acusado de traição, pois tinha-lhes enviado ouro, prata e jóias para além de cartas com informações secretas. Por esta razão, veriam os bens confiscados para a coroa. A viúva Benvinda conseguiria resgatá-los em parte, graças a uma generosa doação ao monarca, no valor de um milhão de reais e

\footnotetext{
${ }^{102}$ IAN/TT, Chancelaria de D. Afonso V, liv. 1, fl. 16v; Estremadura, liv. 8, fl. 70r.

${ }^{103}$ IAN/TT, Chancelaria de D. Afonso $V$, liv. 32, fl. 38v.

${ }^{104}$ IAN/TT, Estremadura, liv. 4, fls. 217v-218r.

${ }^{105}$ IAN/TT, Estremadura, liv. 5, fls. 77v-79r.

${ }^{106}$ IAN/TT, Chancelaria de D. João II, liv. 23, fls. 38r-v.
} 
do açúcar que negociavam na Madeira e que lhes tinham sido confiscados. O pagamento imediato consubstanciou a desistência da dívida que o duque tinha para com Samuel Abravanel e os seus filhos e o restante pela avaliação de alguns bens confiscados que o rei dera a Estêvão Pestana, cavaleiro da casa real ${ }^{107}$.

Também Juda Abravanel e Luna que, tal como Benvinda, se encontravam no reino, recebiam carta de perdão por terem enviado ouro, prata, dinheiros e jóias, cartas e mensagens aos Abravanéis, Isaac e José que se encontravam refugiados em Castela ${ }^{108}$.

Já Isaac Abravanel, filho segundo de Juda, o velho, aparecia referido na década de 1460 como mercador, servidor do rei D. Afonso V e do duque de Bragança. A ligação de Isaac a D. Fernando, conde de Guimarães e futuro duque de Bragança, remontava ao início da década de 1460, pelo menos. Em 1464, este primo do rei intercedia a favor do mercador judeu para que este nunca usasse sinal nas suas vestes, como a lei requeria. D. Afonso $\mathrm{V}$ assinaria a carta de privilégio que concedia tal isenção ${ }^{109}$. Já no ano anterior, este judeu que aparecia identificado como servidor do rei e mercador, recebia o privilégio para se deslocar em mula, poder trazer armas e pousar em estalagens cristãs ${ }^{110}$. Em 1477, Isaac Abravanel e Moisés Latam eram parceiros no trato das moradias da casa real, tendo pago a D. Pedro de Noronha as 4.500 coroas que lhe eram devidas pelo seu casamento ${ }^{111}$. Alguns anos mais tarde, em 1478, o agora duque de Bragança e sua mulher doavam um casal em Queluz a Isaac Abravanel, seu servidor, para ele e todos os seus descendentes, em pagamento dos muitos serviços que este judeu lhes fizera. Em 1487, esta propriedade seria confiscada e a renda dela doada a Lopo de Figueiredo ${ }^{112}$.

${ }^{107}$ IAN/TT, Chancelaria de D. Afonso $V$, liv. 4, fl. 14r; liv. 15, fls. 38v-39r; liv. 28 , fl. 90v; liv. 29, fls. 64r-v; Chancelaria de D. João II, liv. 21, fls. 39v-40r; liv. 23, fls. 38r-v; Estremadura, liv. 5, fls. 77v-79r; liv. 4, fls. 67r-69r.

${ }^{108}$ IAN/TT, Chancelaria de D. João II, liv. 21, fl. 42r.

${ }^{109}$ IAN/TT, Chancelaria de D. Afonso $V$, liv. 8, fl. 126v.

${ }^{110}$ IAN/TT, Chancelaria de D. Afonso V, liv. 9, fl. 92v.

${ }^{111}$ IAN/TT, Chancelaria de D. João II, liv. 6, fls. 133v-135r.

${ }^{112}$ IAN/TT, Chancelaria de D. Afonso V, liv. 32, fls. 77r-v; Estremadura, liv. 9, fl. 
A acusação de participação no financiamento da conspiração dos duques de Bragança e de Viseu por parte de alguns membros desta família levaria ao confisco dos bens e ao exílio forçado de Isaac Abravanel, de seu filho Juda, de José e Jacob seus sobrinhos, e de sua filha Luna casada com o primo José. A fuga de Isaac, que se encontrava no Alentejo quando o duque de Bragança foi preso, teve a conivência de um escudeiro do duque que o avisou e de alguns judeus, seus servidores. Foi o caso de Abraão Galafe, residente em Estremoz, que o acompanhou na ida para Castela, ajudando-o a escapar às justiças régias, pelo que teria também os bens confiscados ${ }^{113}$.

Por carta de perdão de Agosto de 1483, ficámos a saber que, na ausência de Isaac Abravanel em Évora, a sua casa em Lisboa fora assaltada por um Pardo, seu criado, com a conivência de Juda Magriço, alfaiate, os quais acabariam apanhados no assalto por Moisés Haim, guarda da casa de Abravanel. Infelizmente desconhecemos o motivo do assalto que teria o perdão concedido pelo próprio Abravanel ${ }^{114}$.

Em Junho de 1484, D. João II ordenava o confisco de todos os bens móveis e de raiz de Isaac Abravanel, acusando-o de ter participado na traição do duque de Bragança contra o rei. Na sequência do confisco, o monarca doava a um seu servidor, Moisés Latam, em pagamento de serviços prestados à coroa, quer no tempo de $\mathrm{D}$. Afonso $\mathrm{V}$, quer no de $\mathrm{D}$. João II, as casas em que Abravanel residia na Rua do Picoto da judiaria grande. Referia nesta doação, que ordenara o seu derrube para nelas se procurar bens que estariam escondidos, devendo o filho de Moisés, Isaac Latam, reconstruí-las, reconstrução avaliada em 210 cruzados de ouro, quantia que o rei se comprometia a entregar aos herdeiros de Abravanel se as quisessem para $\mathrm{si}^{115}$.

Os imóveis de Isaac Abravanel foram confiscados para a coroa, assim como alguns bens móveis como livros. Umas casas, na judiaria

276r; liv. 7, fls. 4r-5v.

${ }^{113}$ IAN/TT, Chancelaria de D. João II, liv. 26, fl. 136r.

${ }^{114}$ IAN/TT, Chancelaria de D. João II, liv. 24, fl. 34r.

${ }^{115}$ IAN/TT, Chancelaria de D. João II, liv. 21, fl. 98v; Chancelaria de D. Manuel, liv. 16, fls. 48r-v; liv. 40, fls. 22v-23r. 
grande, na Gibitaria, foram repartidas entre mestre Abraão, físico da duquesa D. Isabel, e Isaac Francês ${ }^{116}$. Outras casas, na Rua dos Mercadores da mesma judiaria defronte de outras casas de Isaac Abravanel, seriam aforadas por D. João II, em 1487, a Juda Toledano, servidor do rei, por dois marcos de prata. Eram contíguas a casas de Samuel Abravanel, e confrontavam com casas de Guedelha Gualite e com casas de Moisés Navarro ${ }^{117}$. Abraão Franco, servidor do rei, recebia deste todas as casas que Isaac Abravanel comprara à coroa, na rua da Gibitaria e que pagavam foro à comuna de Lisboa ${ }^{118}$. Outras casas de Isaac, em Évora, na Rua do Reimondo, ou seja, no exterior da judiaria, eram aforadas pelo rei a Brás Álvares, ourives ${ }^{119}$.

Em Junho de 1484, o monarca doava a cadeira vaga de Isaac Abravanel na sinagoga grande de Lisboa a mestre Abraão Abet, seu alfaiate. Uma «seda» que Abravanel tivera nesta casa de oração era doada a Jacob Beirão, servidor do rei ${ }^{120}$. Outra «seda» na nave do meio da referida sinagoga e que pertencera a Juda Abravanel, seu pai, o qual a herdara de D. Sag Ben [sic?], era dada a Moisés Zarco também alfaiate régio ${ }^{121}$.

Isaac Abravanel era, além de mercador rico e judeu culto, um proprietário rural no Alentejo. O almoxarifado de Estremoz entregava para mantimento dos lugares de além-mar 140 móios e 47 alqueires de trigo das propriedades deste judeu ${ }^{122}$. Aqui tinha servidores, como Amado Samaria, residente em Estremoz, que o acompanharia na fuga para Castela $^{123}$. As suas origens em Portugal e a sua relação com o duque de Bragança justificavam a existência de casas suas em Évora. Em 1493 , o rei aforava as casas de Isaac Abravanel nesta judiaria a Samuel Cide

${ }^{116}$ IAN/TT, Chancelaria de D. João II, liv. 14, fls. 58v-59v; Estremadura, liv. 3, fls. $172 \mathrm{r}-173 \mathrm{v}$.

${ }^{117}$ IAN/TT, Chancelaria de D. João II, liv. 19, fls. 30r-v; Estremadura, liv. 3, fl. $177 \mathrm{v}$.

${ }^{118}$ IAN/TT, Chancelaria de D. João II, liv. 22, fls. 60r e 143v; Estremadura, liv. 8, fl. $60 \mathrm{v}$.

${ }^{119}$ IAN/TT, Chancelaria de D. João II, liv. 16, fl. 88r; Odiana, liv. 2, fl. 79r.

${ }^{120}$ IAN/TT, Chancelaria de D. João II, liv. 22, fls. 5v, 60r e 84r.

${ }^{121}$ IAN/TT, Chancelaria de D. João II, liv. 1, fl. 124v.

${ }^{122}$ IAN/TT, Extras, liv. 1, fl. 244v.

${ }^{123}$ IAN/TT, Chancelaria de D. João II, liv. 22, fl. 100r. 
e a sua mulher Palomba, as quais confrontavam com outras casas de Abravanel que o monarca arrendara a Juda Maçoude, as quais ficavam junto à Praça da judiaria e à azinhaga que da Praça ia dar ao quintal de José Abeacar. Outras casas eram aforadas pelo rei a Salomão Fidalgo, alfaiate $^{124}$.

Em Castela, para onde fugiram em 1483-84, estes membros da família Abravanel aproximaram-se da corte real e mantiveram o prestígio de judeus cortesãos que retiravam os seus rendimentos dos lanços sobre as rendas reais e do modo como geriam o dinheiro. Tal como acontecera em Portugal, os Abravanel e outros judeus ricos castelhanos, como os Benveniste, os Senior financiaram parcialmente a conquista de Granada. Quando os reis ordenaram a expulsão da minoria dos seus territórios, a maioria dos seus membros foi apanhada desprevenida para resolver a contento os seus negócios e venda dos seus bens, apesar de ter ocorrido, tempos antes, um primeiro ensaio desta expulsão nos judeus da Andalucía. Isaac Abravanel juntar-se-ia a Abraham Seneor, o velho rabi mor de Castela, na tentativa de dissuadir os reis Isabel e Fernando a executarem o édito de Março de $1492^{125}$.

No entanto, os Abravanel conseguiriam obter o favor régio para a resolução dos inúmeros problemas que se levantavam, após o édito, com os concelhos e os particulares que recusavam pagar-lhes as dívidas. A solução que respondeu à urgência temporal foi acordar com os soberanos uma troca, ou seja, as dívidas dos concelhos e dos particulares passavam para os monarcas como forma de pagamento das rendas que Isaac Abravanel geria e não conseguira receber ${ }^{126}$. Em documento que Suárez Fernández colocava anterior a Agosto de 1492, os reis Isabel e Fernando davam instruções a Luis de Sepúlveda para avaliar as fraudes cometidas por Gómez de Robles, na sequência de uma queixa escrita de Isaac Abravanel contra este sobre o acordo feito com os soberanos acerca das dívidas que o judeu não chegara a receber e lhes trespassara ${ }^{127}$. Ainda em Outubro do mesmo ano, os reis decidiam sobre

\footnotetext{
${ }^{124}$ IAN/TT, Odiana, liv. 4, fls. $177 \mathrm{v}-178 \mathrm{v}$ e $238 \mathrm{v}$.

${ }^{125}$ L. SuÁrez Fernández, La expulsión de los judios de España (Madrid: Mapfre, 1991), 325-328.

${ }^{126}$ SuÁREZ Fernández, Documentos acerca de la expulsión, 403-408 (doc. 184).

127 SuÁrez Fernández, Documentos acerca de la expulsión, 456-458 (doc. 214).
} 
a execução das dívidas que certos particulares tinham para com Isaac Abravanel $^{128}$ que, entretanto, em finais de Julho, partira com a família do porto de Valencia para Itália, tendo iniciado a sua peregrinação e a dos seus familiares por Nápoles, tendo seguido daqui por causa das perseguições aos judeus para $\mathrm{Corfu}^{129}$. Mais tarde fixaria residência em Veneza, enquanto os seus parentes se dispersavam por Ferrara, Nápoles e outros por terras do Turco.

Em Junho, José (Juça) Abravanel, a sua mulher, o seu irmão Jacob obtinham carta régia a desembargar-lhes os bens móveis e de raiz do casal que lhes tinham sido embargados pelo duque D. Álvaro de Çuñiga e pelo mestre de Alcántara, seu irmão, sob a justificação de que José tinha certas dívidas para com eles das quais a mulher e o irmão tinham sido os fiadores. Alegava José ter pago muito mais do que recebera pelas rendas de Plasencia, durante os anos de 1487 e 1488 . Os monarcas ordenavam que fossem libertados José, a sua mulher e o seu irmão Jacob, assim como os seus feitores e criados porquanto ficavam no reino por fiadores Luis de Alcalá, vizinho e regedor de Madrid, e Fernán Núñez Coronel, vizinho de Segovia (ol. Abraham Seneor). Autorizava também que pudessem sair livremente do reino ${ }^{130}$.

Por sua vez, Jacob Abravanel queixar-se-ia aos monarcas de que um seu pastor fugira para Portugal com as cento e quarenta vacas que tinha num cerrado sito no termo de Alcántara e acrescentava aquele que o seu pastor fora para Portugal com o gado porque sabia que Jacob Abravanel não podia entrar nele ${ }^{131}$.

Em Portugal, Juda Abravanel, talvez o filho de Isaac, teve necessidade de um empréstimo de duzentos mil reais que obteve de Moisés Latam, dando como aval ou hipoteca as suas casas na judiaria. Acordou que enquanto o empréstimo não fosse pago, Moisés Latam receberia o dinheiro dos alugueres. Este acordo viria a ser entendido como usurário pelo que o rei D. Manuel confiscaria, mais tarde, as ditas casas e doava-as a Francisco de Pedrosa ${ }^{132}$.

\footnotetext{
${ }^{128}$ SuÁrez Fernández, Documentos acerca de la expulsión, $472-473$ (doc. 224).

${ }^{129}$ AMADOR DE LOS Ríos, Historia social, política y religiosa, 725.

${ }^{130}$ SuÁrez Fernández, Documentos acerca de la expulsión, 435-437 (docs. 201-202).

${ }^{131}$ SuÁREZ FernándeZ, Documentos acerca de la expulsión, 439-440 (doc. 204).

${ }^{132}$ IAN/TT, Estremadura, liv. 4, fls. 25v-26r.
} 
Na terceira geração de Abravanéis nascida em Portugal, temos os filhos de Samuel e de Benvinda, José e Jacob, que já mencionámos como participantes na conspiração contra D. João II, devendo este último ser o $Y a$, o moço que encontrámos em documentação da década de 70. Mas também, nos surge um Samuel Abravanel, o moço, em documentos régios datados de 1473 e 1487, que não pode ser identificado com o benjamim de Isaac Abravanel que, segundo os linhagistas judaicos, teria nascido em 1473, e de quem nós não temos informação sobre os seus progenitores. Já o Juda Abravanel que obteve em 1473, tal como este seu parente, carta de privilégio de D. Afonso $\mathrm{V}$ pode ser associado ao filho de Isaac Abravanel, o futuro poeta e filósofo Leão Hebreu $^{133}$ e que, em 1487, nos surgia como estando casado com Luna ${ }^{134}$.

Em 1501, Henrique Fernandes Abravanel, mercador, aforava umas casas na Rua da Ferraria, na ex-judiaria grande de Lisboa, aforamento que tinha sido iniciado por sua tia Leonor Fernandes que, entretanto, falecera ${ }^{135}$. Entre as casas da ex-judiaria grande, doadas, em 1505, à ordem de Cristo, estavam as dos herdeiros de Leonor Fernandes (ol. Luna Abravanel $)^{136}$. Em 1512, D. Manuel ordenava que fosse pago a Henrique Fernandes Abarbanelli, neto de $Y a$ Abrabanel e sobrinho de Juda Abravanel, 400000 reais da conta de 800000 reais que foram despachados em 1511 e em 1512, por razão de uma dívida que a coroa tinha para com o seu avô no valor de 1540464 reais, relativamente ao tempo em que $\mathrm{Ya}$ Abravanel tivera o trato das moradias de D. Diogo, entre 1477 e 1480 e da dívida que havia para com Luna, mulher de Juda Abravanel, de tudo quanto este recebeu e gastou com o arrendamento da vintena da Guiné, em 1482-83, na parceria que tinha com Catarina Leme no tempo do mesmo duque ${ }^{137}$.

Como já referimos, os Abravanel caíram em desgraça junto de D. João II por acusação de terem participado, financiando e conhecendo a conspiração para matar o príncipe D. Afonso e o próprio rei. A sua ligação ínti-

${ }^{133}$ IAN/TT, Chancelaria de D. Afonso V, liv. 33, fl. 182v; Chancelaria de D. João II, liv. 19, fls. 30r-v; Estremadura, liv. 3, fl. 177v; Chancelaria de D. Afonso V, liv. 33, fl. $224 \mathrm{v}$, respectivamente.

${ }^{134}$ IAN/TT, Chancelaria de D. João II, liv. 21, fl. 42.

${ }^{135}$ IAN/TT, Chancelaria de D. Manuel, liv. 6, fls. 51r-v.

${ }^{136}$ IAN/TT, Chancelaria de D. Manuel, liv. 4, fl. 24v-25r.

${ }^{137}$ IAN/TT, Corpo Cronológico, Parte I, maço 10, doc. $\mathrm{n}^{\circ} 165$. 
ma aos duques de Bragança e de Viseu e aos seus parentes, notemos que muitos destes fidalgos se aposentavam na judiaria em casa dos Abravanel, explicava a protecção e até amizade que os unia. D. João II caracterizava Isaac Abravanel como alguém que era servidor e amigo do duque de Bragança e de toda a sua casa e acrescentava que este mercador era muito rico e afazendado. Isaac e José Abravanel, filho de Samuel Abravanel e genro daquele, estendiam a sua influência pelo Alentejo, terras daquele fidalgo. Em Moura, encontravam-se para recolher o dinheiro a ser entregue ao duque de Bragança. Na Vidigueira, Isaac Abravanel recebia Tristão de Vila Real, um castelhano que estaria dentro do complot e que era portador de várias cartas para o duque e para os dois judeus, sobre o financiamento dos soldados que invadissem o reino. Isaac estava em Arraiolos quando fugira para Castela, após as mortes dos duques de Bragança e de Viseu.

José Abravanel, filho de Samuel e genro de Isaac, era servidor de D. Diogo, duque de Beja e tratador das suas moradias, para além de auferir da confiança e amizade do cunhado do rei. Fora ele quem aliciara o sogro para financiar os projectos dos referidos duques. Conseguiria arranjar 120000 cruzados. José estava em Setúbal com o duque de Viseu, quando o rei o matou e, mesmo sendo sábado, saiu da vila e fugiu do reino. Ambos seriam condenados à forca ${ }^{138}$, o que não sucederia porquanto se exilaram em Castela, onde viveram até Março de 1492. Suárez Fernandez apresenta José Abravanel como irmão de Isaac ${ }^{139}$, o que não nos parece ser confirmado pela documentação portuguesa. O José que acompanhou Isaac era seu genro e filho de Samuel e de Benvinda Abravanel. O José Abravanel, o velho, irmão de Juda e tio de Isaac, seria falecido na altura do exílio de Portugal.

Apesar de ser um pouco difícil lidar com as designações de parentesco, pois nem sempre «sobrinho» ou «primo» têm o mesmo significado que nós damos hoje a idênticas relações, porque tanto podem ser em primeiro grau como segundo grau, um neto pode ser um sobrinho-neto ou um bisneto, apresentamos uma nova tentativa de proposta genealógica para esta família em Portugal.

${ }^{138}$ A. Braamcamp FreIre, «As conspirações no reinado de D. João II. Documentos», Archivo Histórico Portuguez. II (1904), 31-33 e 346-348.

139 SuÁrez Fernández, La expulsión de los judios, 262-263. 
Verificamos a existência de endogamia entre os membros desta família pelo casamento entre primos direitos, como era o caso da filha de Isaac com o seu primo José, filho de Samuel ou de Juda, filho de Isaac com
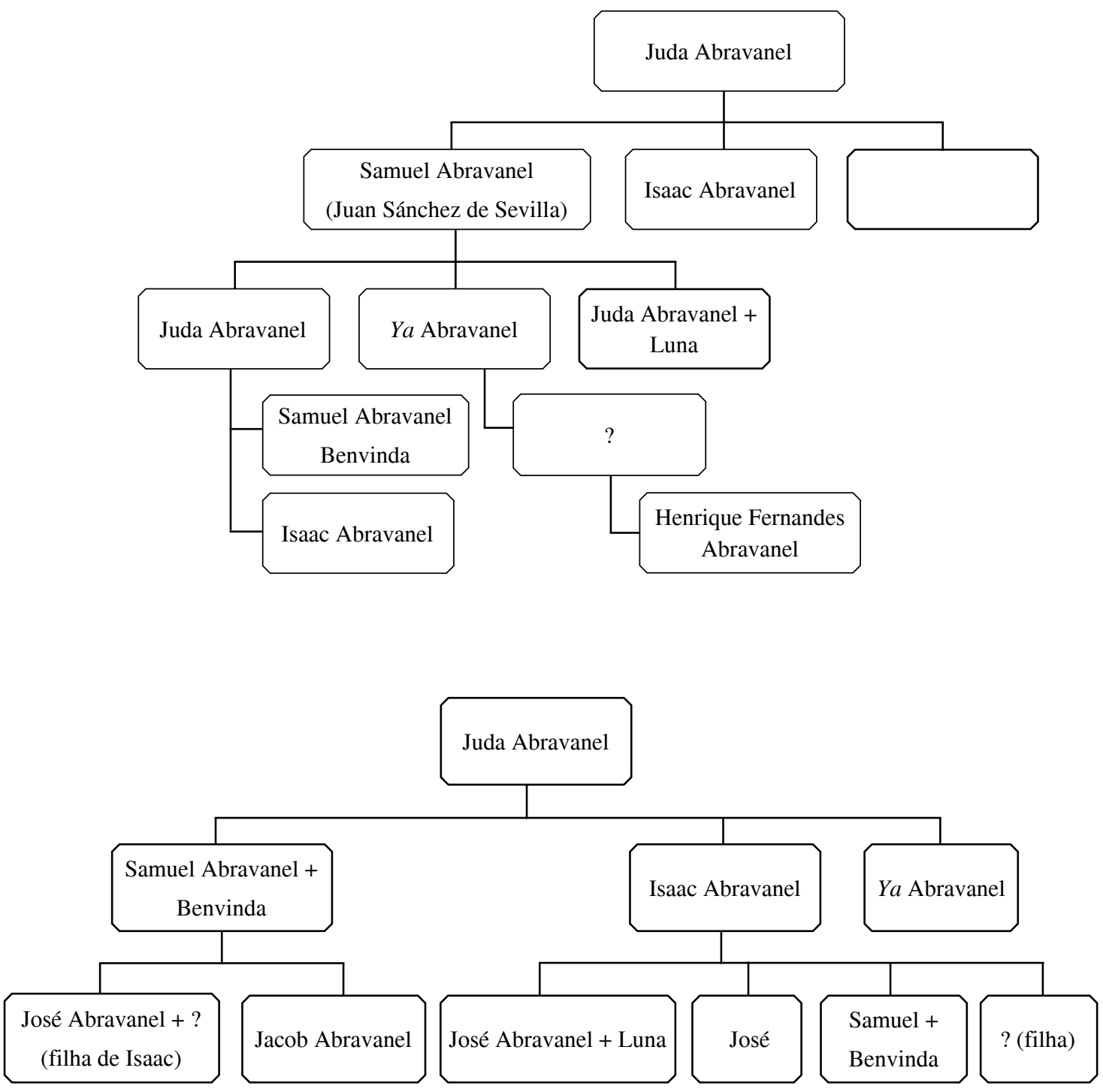
Luna, filha de $\mathrm{Ya}$ Abravanel. O filho mais novo de Isaac, Samuel, casaria com Benvinda, filha de $Y a$ ou Jacob Abravanel, seu tio.

Após o baptismo forçado, o apelido Abravanel permaneceria como alcunha/apelido judaico dos descendentes cristãos, como o atrás mencionado Henrique Fernandes Abravanel, neto de $Y a$ Abravanel e sobrinho de Luna, baptizada com o nome de Leonor Fernandes, falecida pouco depois do baptismo. Ou Francisco Lopes Abravanel, mercador de Lisboa, testemunha a favor de mestre Tomás, preso na Inquisição de Lisboa ${ }^{140}$.

\subsection{Outros apelidos hispano-judaicos em Portugal}

Outros apelidos de origem não toponímica podem fazer-nos supor que certos indivíduos poderiam ter tido a sua origem além fronteiras, como sucedeu com os Abravanel, naturais de Sevilla. Seria o caso de Jacob ben Adret, criado de Juda Abravanel, servidor do rei ${ }^{141}$. Anos mais tarde, um Jacob ben Adret negociava a compra de sabão com um mestre Isaac, perante o escrivão Juda Barcelonim ${ }^{142}$. Ou mestre Judas Benziza, físico e servidor da rainha D. Leonor, princesa aragonesa, viúva de D. Duarte ${ }^{143}$. Duas outras famílias hispano-judaicas com membros de um e outro lado da fronteira eram os Aboa e os Caro. Estes últimos aparecem como mesteirais, como o alfaiate Isaac Caro, residente em Évora, ou o companheiro de ofício Moisés Caro, morador em Trancoso, ou o alfaiate Jacob Aboa, em Bragança. Mas os Caro, em Trancoso, teriam um físico em mestre Isaac Caro, filho de Abraão Caro ${ }^{144}$. E outros desempenhariam funções importantes na escrivaninha e no tabeliado das comunas, alcançando uma certa notoriedade social. Assim, em 1490, um Isaac Caro exercia a função de tabelião geral das comunas e das judiarias do reino, função exercida desde $1482^{145}$ e, no ano seguinte, um Abraão Caro era nomeado tabelião

${ }^{140}$ IAN/TT, Inquisição de Lisboa, no 58 ([ano de] 1539).

${ }^{141}$ IAN/TT, Chancelaria de D. Afonso $V$, liv. 15, fl. 174v.

${ }^{142}$ IAN/TT, Chancelaria de D. João II, liv. 2, fl. 90r.

${ }^{143}$ IAN/TT, Chancelaria de D. Afonso $V$, liv. 15, fl. 76r.

${ }^{144}$ IAN/TT, Chancelaria de D. Afonso V, liv. 15, fl. 159v; Chancelaria de D. João II, liv. 8, fl. $137 \mathrm{v}$

${ }^{145}$ IAN/TT, Chancelaria de D. João II, liv. 13, fl. 93v; liv. 16, fl. 58r; liv. 6, fl. 9r. 
do rei na comuna de Évora em substituição de Samuel Cide ${ }^{146}$. Em Lisboa, residiam mestre Samuel Caro e seu filho Isaac Caro que, em 1463, era nomeado tabelião geral das comunas do reino, tal como fora seu pai que a tal cargo renunciara ${ }^{147}$.

Tal como os Caro, também os Aboa se encontravam dispersos no reino. Uns foram residir para Vila do Conde, nos arredores do Porto. Aqui viviam Samuel e Juça Aboa, rendeiros. Este último recebera permissão de D. Afonso $\mathrm{V}$ para poder habitar numas casas que construíra na parte cristã. Um outro membro da família ou pelo menos usava o mesmo apelido, mestre Aboa fora acusado de burlão e preso em casa de Juça Aboa em vez de o ser na cadeia, porque era rendeiro do rei ${ }^{148}$. Em 1481, um José Aboa recebia carta para exercer a medicina e, residindo em Braga, um Samuel Aboa obtinha permissão para se deslocar em mula ${ }^{149}$. Um outro Aboa, residia no Mogadouro e obtinha do rei permissão para não apresentar o sinal no exterior do vestuário sempre que se deslocasse e durante os três primeiros dias em que chegasse a um local ${ }^{150}$. Um Jacob Aboa fora recebedor dos dinheiros do empréstimo que os judeus de Chaves deram a D. Afonso V para a guerra contra Castela ${ }^{151}$.

O mesmo se passou com os Abet e os Saba que encontramos referenciados desde os finais do século XIV, em Lisboa. Um Moisés Saba residia na ferraria da judiaria grande, em $1396^{152}$. D. Duarte aforava a título perpétuo a Isaac Saba umas casas na judiaria grande, à porta do Chancudo, as quais passariam a Salomão Abet por ter casado com uma filha daquele. Este, por sua vez, compraria outras duas casas contíguas que tinham pertencido a Moisés Fanamel e a Simão, tosador ${ }^{153}$. Um Moisés

${ }^{146}$ IAN/TT, Chancelaria de D. João II, liv. 10, fl 149v.

${ }^{147}$ IAN/TT, Chancelaria de D. Afonso V, liv. 9, fl.80.

${ }^{148}$ IAN/TT, Chancelaria de D. João II, liv. 18, fls. 23v-24r; liv.26, fl. 122e; Chancelaria de D. Afonso V, liv. 32, fls. 47v-48r, $92 \mathrm{v}$.

${ }^{149}$ IAN/TT, Chancelaria de D. Afonso $V$, liv. 26, fl. 116v e 136r.

${ }^{150}$ IAN/TT, Chancelaria de D. Afonso $V$, liv. 36, fl. 82r.

${ }^{151}$ IAN/TT, Chancelaria de D. João II, liv. 19, fl. 91r.

${ }^{152}$ IAN/TT, Chancelaria de D. João I, liv. 2, fl. 116v.

${ }^{153}$ IAN/TT, Chancelaria de D. Afonso V, liv. 35, fl. 104r; liv. 13, fls. 74v-75r; Estremadura, liv. 4, fls. 158v-160r. 
Abet, mercador, residente em Lisboa, fugira para Castela com receio de ser preso por devedor, pois fora roubado quando se dirigira a Setúbal para estar presente no casamento de uma sobrinha. $\mathrm{O}$ assalto de que fora vítima deixara-o sem qualquer capacidade de poder responder aos seus compromissos económicos ${ }^{154}$. Outro Abet residente em Lisboa tinha o nome de David ${ }^{155}$. Os Abet eram mesteirais. Um deles, já referido, mestre Abraão Abet seria alfaiate de D. João II, sendo recompensado por este porque servira D. Afonso V nas conquistas de Tânger e Arzila e o príncipe na batalha de Toro, indo em pessoa com armas e cavalo. Foi nomeado para o cargo de contador mor das comunas do reino, função que adviera da divisão e extinção do arrabiado mor de Portugal no tempo de D. Afonso $\mathrm{V}^{156}$. Um Salomão Abet era rabi da comuna de Lisboa em $1491{ }^{157}$. Outros Abet residiam em Castelo de Vide, como Abraão Abet que acusara Fernão Lourenço, vassalo do rei, de passar para Castela prata, ouro, açúcar e outras mercadorias ${ }^{158}$. O físico mestre Isaac Abet residia em Tânger e ficaria isento do pagamento da sisa judenga e outros direitos, onde quer que estivesse, em recompensa pelos serviços prestados a D. João II $^{159}$.

Alguns judeus de proveniência castelhana ajudaram a povoar as judiarias portuguesas, como Haim de Cáceres que foi residir junto ao adro de S. Vicente na Guarda. O seu avô, Isaac de Cáceres veio morar para esta cidade no tempo de D. Dinis. Por sua morte, a casa passara a Jacob de Castro e deste para Haim. O apelido Cáceres permaneceria entre os judeus desta cidade ainda no século XV. Aqui um Moisés de Cáceres aforara a D. Duarte seis casas e um curral, nas traseiras dos açougues velhos e um Daniel de Cáceres aforava em enfiteuse um chão na mesma judiaria ${ }^{160}$ Outro vizinho era Junça de Calahorra cuja casa confinava com a de Me-

\footnotetext{
${ }^{154}$ IAN/TT, Chancelaria de D. Afonso $V$, liv. 10, fl. 25r.

${ }^{155}$ IAN/TT, Livro dos foros del-rei, NA 319, fl. 38r.

${ }^{156}$ IAN/TT, Chancelaria de D. João II, liv. 1, fl. 62v.

${ }^{157}$ IAN/TT, Chancelaria de D. João II, liv. 11, fls. 119r-v.

${ }^{158}$ IAN/TT, Chancelaria de D. João II, liv. 4, fls. 93v-94r.

${ }^{159}$ IAN/TT, Chancelaria de D. João II, liv. 2, fl. 14v.

${ }^{160}$ IAN/TT, Chancelaria de D. Duarte, liv. 1, fl. 174r; Beira, liv. 2, fls. 24r-25r,
} 236v-237v. 
naém Castelão ${ }^{161}$. Alguns fixavam-se como mesteirais, como o castelhano José, tecelão, em Borba, ou os sapateiros Judas e Jacob Lerma, em Vila Viçosa, ou o alfaiate Saragocim em Montemor-o-Novo ${ }^{162}$. Outros eram mercadores e médicos como os de Vitória, no Porto, de que era exemplo mestre Moisés de Vitória, natural desta cidade portuguesa ${ }^{163}$.

Outros judeus cujos apelidos recordavam origens peninsulares chegaram junto da família real devido à sua arte. Foi o caso de Moisés de Leão que era ourives da condessa de Barcelos, casada com o filho bastardo de D. João I ${ }^{164}$. Moisés de Medina, ferreiro, obtinha de D. Afonso V, uma carta régia isentando-o de dar aposentadoria nas suas casas em Santarém, graças à intercessão de mestre Mateus Pisano, secretário e mestre do rei ${ }^{165}$.

Outros vinham da Catalunha, como indicava o apelido Catalão que encontramos em vários concelhos do reino, nomeadamente em Lisboa, como aquele Catalão dos conselhos económicos e financeiros a $\mathrm{D}$. Afonso V. Aqui residiam José Catalão e seu filho Moisés. Este substituiria David Negro, em 1463, nos cargos de contador dos feitos e das custas e de inquiridor na comuna ${ }^{166}$. Outra carta de privilégio foi dada a José Catalão, alfaiate, para ele e os seus trabalhadores poderem pousar em estalagens de cristãos e arrendar as rendas de mosteiros ${ }^{167}$. Também médicos e mercadores eram alguns dos judeus de apelido Catalão, como mestre Eliézer Catalão ${ }^{168}$.

Outros eram especieiros, como os Carmonis, residentes em Lisboa ${ }^{169}$.

Calahorra era malheiro da guarda do capitão dos ginetes do rei pelo que tinha como função limpar e reparar as armas e a malha das vestes destes. Com ele tinha obreiros e aprendizes que o ajudavam e o acompanhavam nas suas deslocações com a corte. Pela sua função e por ser cor-

${ }^{161}$ Chancelarias Portuguesas. D. Duarte, vol. I-2, (liv.1, fl. 165v-166v,173v, 174r).

${ }^{162}$ IAN/TT, Chancelaria de D. Afonso V, liv. 15, fl. 159v.

${ }^{163}$ IAN/TT, Chancelaria de D. João II, liv. 10, fls. 116v.

${ }^{164}$ IAN/TT, Chancelaria de D. Afonso $V$, liv. 23, fl. 5r.

${ }^{165}$ IAN/TT, Chancelaria de D. Afonso $V$, liv. 11, fl. 46r.

${ }^{166}$ IAN/TT, Chancelaria de D. Afonso $V$, liv. 9, fl. 65v.

${ }^{167}$ IAN/TT, Chancelaria de D. Afonso V, liv. 30, fl. 25v.

${ }^{168}$ IAN/TT, Chancelaria de D. João II, liv. 15, fl. 101v.

${ }^{169}$ IAN/TT, Chancelaria de D. João I, liv. 4, fl. 36r. 
tesão, podia armar a tenda em qualquer praça ou espaço específico ${ }^{170}$. O mesmo, ou um homónimo de apelido Calahorra, era armeiro do rei e vivia na corte, tendo os privilégios e as regalias dos oficiais do rei, cortesãos e moradores na casa real ${ }^{171}$. Também, em Évora, residiam uns Calahorra. Jacob de Calahorra exercia o ofício de armeiro do rei D. João II. Um seu sobrinho tinha o apelido Matrotel. Salomão Matrotel era moço e alfaiate. Fora preso por roubar certa malha para as armaduras dos fidalgos pelo que fora açoitado publicamente e, por isso, ficara infamado e com ele a família. O rei relevar-lhe-ia a infâmia porquanto era de boa geração e bem aparentado ${ }^{172}$.

Samuel Toledano, almoxarife do rei em Torres Novas, viu os seus bens móveis e de raiz confiscados por D. Fernando e doados a Afonso Vasques Correia, escudeiro ${ }^{173}$. Outro Toledano, de seu nome Juça, e sua mulher Formosa aforavam, em 1385, quatro casais em Paço de Rei, próximo de $\mathrm{Gaia}^{174}$. Em meados do século XV, os Toledano estavam cruzados pelo casamento com a família de mestre Moisés (Latam?), alfaiate do rei e aproximavam-se da corte, pois só assim se explica que o príncipe D. João tivesse enviado um «embaixador» para que Salomão Toledano regressasse a casa e fizesse as pazes com a mulher e os filhos. Esta era tia de mestre Moisés ${ }^{175}$. Em 1475, um Judas Toledano, morador em Lisboa, era identificado com a categoria de «servidor do rei» ${ }^{176}$. Em 1486, um Juda Toledano era rendeiro dos portos, pelo que ordenara, em nome do rei, a prisão de Samuel Abez, morador em Santarém, porquanto este saíra para Castela por um porto e entrara no reino com 20 peças de pano por um porto defeso para fugir aos direitos reais. Para não ter a mercadoria confiscada, Samuel Abez chegaria a um acordo tendo entregue 19000 reais $^{177}$.

\footnotetext{
${ }^{170}$ IAN/TT, Chancelaria de D. João II, liv. 26, fl. 14r.

${ }^{171}$ IAN/TT, Chancelaria de D. João II, liv. 21, fls. 73r-v.

${ }^{172}$ IAN/TT, Chancelaria de D. João II, liv. 3, fl. 76r.

${ }^{173}$ IAN/TT, Chancelaria de D. João I, liv. 5, fl. 40v; liv. 1, fl. 190r.

${ }^{174}$ IAN/TT, Chancelaria de D. João I, liv. 1, fl. 77r.

${ }^{175}$ IAN/TT, Chancelaria de D. Afonso V, liv. 3, fls. 27v-28r.

${ }^{176}$ IAN/TT, Chancelaria de D. Afonso V, liv. 26, fl. 179v.

${ }^{177}$ IAN/TT, Chancelaria de D. João II, liv. 19, fl. 70v.
} 
Isaac Penafiel, mercador, residente em Lisboa recebia uma carta de privilégio sui generis. Toda a mercadoria que ele transportasse clandestinamente sem pagar os direitos devidos à coroa não seria confiscada, devendo ele pagá-la a dobrar se fosse descoberto ${ }^{178}$. Era uma maneira de o rei não perder os seus direitos nem o judeu a sua mercadoria.

Os Penafiel tal como os Toledano apresentavam-se em parceria com outros judeus nos lanços dos pagamentos das moradias da casa real, quer de D. João II, quer de D. Manuel, duque de Beja e príncipe, quer, mais tarde, rei. Em 1495, Isaac Penafiel juntamente com Isaac Beacar e Moisés Benafaçam ficaram com o trato das moradias do duque de Beja, tendo recebido 3596000 reais pagos pelas rendas da casa da Mina, pelos açúcares da Madeira e por outras rendas desta ilha ${ }^{179}$. Juda Toledano, mercador, rendeiro da chancelaria e servidor do rei recebia carta de privilégio, isentando-o de pagamento de portagens e de alguns ramos do serviço real que cada judeu devia pagar à coroa, porquanto andava sempre na corte ao serviço do rei. Este seria o rendeiro preferido por D. João II. Em 1490, doava-lhe vitaliciamente as casas de Salomão Negro defronte da sinagoga grande de Lisboa, que o rei tinha confiscado para a coroa e justificava a doação elogiando o seu serviço como rendeiro do rei e, sobretudo, como rendeiro das sisas dos panos delgados em todo o reino, para a qual contribuíra com um crescimento de seis milhões de reais sobre os restantes rendeiros que fizeram os seus lanços nesta renda ${ }^{180}$.

Outros eram médicos como Samuel Toledano, físico em Évora ${ }^{181}$. Aliás, os Toledano tiveram como primeira residência esta cidade antes de aparecerem em Lisboa. Eram físicos, como mestre Judas, pai de Samuel $^{182}$. Outros Toledano residiam em Torres Vedras onde se cruzavam com os Alguadix, também eles de origem castelhana. Juda Alguadix casava com Cinfa, filha de Anto Toledano ${ }^{183}$.

\footnotetext{
${ }^{178}$ IAN/TT, Chancelaria de D. Afonso V, liv. 30, fl. 145v.

${ }^{179}$ IAN/TT, Extras, liv. 1, fl. 163v.

${ }^{180}$ IAN/TT, Chancelaria de D. João II, liv. 1, fl. 45r; liv. 12, fl. 124v.

${ }^{181}$ IAN/TT, Chancelaria de D. Afonso V, liv. 4, fl. 59r.

${ }^{182}$ IAN/TT, Chancelaria de D. Afonso V, liv. 15, fl. 159r.

${ }^{183}$ IAN/TT, Chancelaria de D. João II, liv. 17, fl. 122v.
} 
Salomão de Illescas residia em Évora e fora perfilhado por D. Benvinda $^{184}$. Outro de Illescas, Abraão, era identificado como criado de mestre Moisés Vivas, mercador, rendeiro da chancelaria real. Um outro, Isaac de Illescas, era mercador em Évora e recebia carta de privilégio do rei para se deslocar no reino em besta muar e com armas ${ }^{185}$. Quando da expulsão dos judeus de Portugal, Maria Dias, viúva de Mail de Illescas, iria viver para Badajoz ${ }^{186}$.

Isaac Castelão, residente em Lisboa, roubara Salomão Ardutel, judeu castelhano, alfaiate, também aqui morador. O rabi Nacim Faiam, mercador, decidira fazer uma inquirição devassa sobre o roubo apesar de a vítima não se ter queixado às autoridades, pelo que Isaac Castelão fugira e inscrevera-se no livro dos homiziados tendo ido servir o soberano em Ceuta ${ }^{187}$.

Já Jacob Castelão, servidor do rei e residente em Braga, recebia os bens de D. Reina, castelhana, moradora no Porto, a qual falecera sem herdeiros nem testamento pelo que os seus bens pertenciam à coroa pelo que $\mathrm{D}$. Afonso $\mathrm{V}$ os dera àquele seu servidor ${ }^{188}$. Outro Castelão residia no Porto e devia ser um judeu rico e com linhagem. Moisés Castelão era servidor deste monarca e recebeu deste permissão para gravar nas portas e nas janelas das casas que construía na judiaria do Olival, no Porto, um castelo e um alão como símbolo das suas $\operatorname{armas}^{189}$.

De Nájera era a família do rabi Salomão Najarim, residente em Lisboa, ou a de Isaac Najarim, morador em Vila Franca, no ano de $1455^{190}$. Em 1487, um Belhamim Najarim, morador em Lisboa, recebia carta de D. João II, autorizando-o a negociar em terras de mouros com mercadorias do reino ou importadas, excepto aquelas que eram

\footnotetext{
${ }^{184}$ IAN/TT, Chancelaria de D. Afonso $V$, liv. 24, fl. 32r.

${ }^{185}$ IAN/TT, Chancelaria de D. Afonso $V$, liv. 30, fl. 122v e 133v.

${ }^{186}$ Évora, Arquivo do Cabido da Sé, livro CEC-6_VII, fls. 33r-34v.

${ }^{187}$ IAN/TT, Chancelaria de D. Afonso $V$, liv. 8, fl. 109r.

${ }^{188}$ IAN/TT, Chancelaria de D. Afonso $V$, liv. 35, fl. 25r.

${ }^{189}$ IAN/TT, Chancelaria de D. Afonso $V$, liv. 32, fl. 63r.

${ }^{190}$ IAN/TT, Chancelaria de D. Afonso V, liv. 15, fl. 79r, 165r.
} 
proibidas pelo papa ou aquelas de que o rei tinha monopólio para o comércio da Guiné e costa da Mina ${ }^{191}$.

Em Évora, os Sória e os Zarrel eram parentes e apareciam a conceder o perdão a Gomes Dinis, morador em Montemor-o-Novo, pela tentativa de violação de Lediça, filha de Isaac Zarrel, e pelo roubo de dinheiros, ouro, prata e coiros a outros membros da família ${ }^{192}$.

Os Valencim encontravam-se presentes em Lamego e em Lisboa. Eram preferencialmente mercadores e médicos ${ }^{193}$. Em 1455, Judas Valencim, mercador, e Missol, obtinham carta de contrato ou de entrada no concelho pela qual pagaram uma dobra de banda. Anos depois emprazavam em enfiteuse parte do rossio de Lamego à porta da judiaria para acrescentamento de casas, boticas e portais que já traziam $^{194}$. Um Juda Valencim, servidor de D. Afonso V, o mesmo ou um seu parente homónimo, tinha a permissão para poder abrir uma porta na tenda que tinha na Praça da cidade e por onde podia entrar e sair das suas casas na judiaria, em pagamento de serviços feitos ao $\mathrm{rei}^{195}$. Os Valencim pertenciam à elite judaica de Lamego. Mestre Jacob Valencim era cirurgião e oftalmologista nesta cidade e requeria à comuna, encabeçada por Judas Valencim, rabi da comuna em 1456, juntamente com os vereadores Jacob Pardo e Juça Crescente, que o isentasse do pagamento dos tributos à comuna uma vez que exercia a medicina gratuitamente ${ }^{196}$.

Entre outras famílias de origem castelhana que se fixaram no reino, ao longo do século XV, temos os Benveniste, os Usque, os Cassuto, os Çacuto ${ }^{197}$, os Benazo. Estes dois últimos apelidos apareceram

${ }^{191}$ IAN/TT, Chancelaria de D. João II, liv. 19, fl. 27v.

${ }^{192}$ IAN/TT, Chancelaria de D. João II, liv. 15, fl. 31v.

${ }^{193}$ IAN/TT, Chancelaria de D. Afonso V, liv. 15, fl. 159r; Chancelaria de D. João II, liv. 4, fl. 36v.

${ }^{194}$ IAN/TT, Beira, liv. 2, fls. 5r-6v.

${ }^{195}$ IAN/TT, Chancelaria de D. Afonso $V$, liv. 32, fl. 63r.

${ }^{196}$ IAN/TT, Chancelaria de D. Afonso V, liv. 9, fls. 138r-v.

${ }^{197}$ Translitero o nome na sua grafia quatrocentista e quinhentista este apelido judaico e recordo que a sua grafia Çacuto se assemelha à grafia medieval de Çamora, actualmente Zamora. 
predominantemente na Beira: Gouveia, Castelo Branco, Pinhel. No entanto, encontramos Cassuto também em Lisboa, enquanto os Usque se dispersaram por Beja, Coimbra, Figueiró, nos arredores desta cidade $^{198}$. Os antepassados do célebre autor das Consolações às tribulações de Israel, Samuel Usque eram predominantemente mesteirais. Em Coimbra viveu um Samuel Usque, ourives, que recebeu de D. Afonso $\mathrm{V}$ o privilégio de escusa no desempenho de cargos na comuna ou ofícios na judiaria, contra sua vontade. Idêntica carta obteve Haim Usque, ourives, residente também em Coimbra ${ }^{199}$.

Já os Benveniste instalaram-se em Lamego, onde Abraão Benveniste e a sua mulher Ruga aforaram um chão por detrás da judiaria desta cidade frente ao campo do tavolado, o qual confrontava com a casa dos contos do rei e com casas destes judeus ${ }^{200}$.

Outros usavam o apelido Montesinho, como Isaac, natural de Ponte de Lima, preso em Lisboa por difamar a religião católica, ou os Montesinho que se fixaram em Aveiro, ou os alfaiates Jacob e Salomão que se encontravam radicados em Braga, em 1442, e que por aqui permaneceriam até à expulsão ${ }^{201}$. Também o apelido de Castro podia querer identificar uma origem castelhana. Assim supomos no caso de Sem Tob de Castro, residente na Guarda, que na década de 1460, partiu com a família para Castela sem autorização do rei, pelo que em 1480 o rei doava os seus bens a Juça Soleima ${ }^{202}$.

Já mais difícil era saber a origem da família Palaçano que teria um grande representante no judeu cortesão Guedelha Palaçano. Era um mercador rico, servidor de D. Afonso V que obteve deste a permissão de se deslocar em mula com sela e freio ${ }^{203}$, certamente em recompensa

${ }^{198}$ Samuel Usque (1464, Beja), IAN/TT, Chancelaria de D. Afonso V, liv. 8, fl. 53v; Isaac Usque, curtidor, Samuel e Haim Usque, ourives, (1442, 1462 Coimbra), IAN/TT, Chancelaria de D. Afonso V, liv. 23, fl. 83v, liv. 1, fl. 77v; Jacob Usque, sapateiro (1442, Figueiró), IAN/TT, Chancelaria de D. Afonso V, liv. 23, fl. 104r, etc.

${ }^{199}$ IAN/TT, Chancelaria de D. Afonso $V$, liv. 1 , fl. 77v.

${ }^{200}$ IAN/TT, Beira, liv. 2, fls. 177v-178v.

${ }^{201}$ IAN/TT, Chancelaria de D. João II, liv. 8, fl. 15r; Chancelaria de D. Afonso V, liv. 31, fl. 117r; liv. 23, fl. 103v.

${ }^{202}$ IAN/TT, Chancelaria de D. Afonso $V$, liv. 32, fl. $14 \mathrm{v}$.

${ }^{203}$ IAN/TT, Chancelaria de D. Afonso $V$, liv. 31, fl. 3r. 
pelos muitos serviços que lhe prestou. Não esqueçamos que ele alcançou a permissão de, com barco seu, acompanhar as caravelas que desceram ao longo da costa de África, o que nos pode fazer supor que este judeu começou a sua carreira na corte ao serviço do infante D. Henrique antes de passar para o do rei, junto do qual, segundo o cronista João de Barros, se tinha exaltado na guerra contra os mouros ${ }^{204}$. Um seu neto usava o apelido Sasson. Moisés Sasson obteve permissão para aforar um casal em Sintra à ponte Pedrinha ${ }^{205}$.

(Continuará)

${ }^{204}$ João de BArros, Da Ásia. Década Primeira (Lisboa: Livraria Sam Carlos, 1973), 86-87 e 115-116 (Parte I, Livro I, cap XI).

${ }^{205}$ IAN/TT, Chancelaria de D. Afonso V, liv. 32, fl. 142r. 


\section{APÉNDICE ${ }^{206}$}

Lisboa, 12 de Outubro de 1396

Acta de reclamación realizada por el escriba Salomón Navarro, de Judá Navarro contra el Arraby môr Moisés de Leiría. Judá Navarro afirma no haber recibido más que 900 «livras de dineiros» de las 1.600 inicialmente estipuladas para la venta de una Biblia en 1384.

${ }_{295 v}$ Saibam todos quantos este instrumento de venda virem que na era de mil e quatrocentos e trinta e quatro anos, doze dias de Outubro, em Lisboa, nas casas de morada de mestre Moisés de Leiria, físico de nosso senhor El-Rei, e arrabi mor das comunas dos judeus dos reinos de Portugal e do Algarve, em presença de mim Salomão Navarro, tabelião do dito senhor Rei na comuna dos judeus da dita cidade e das testemunhas que adiante são escritas, apareceu Judas Navarro, morador na dita cidade, filho de Moisés Navarro, por si de uma parte, e dona Milia, mulher do dito mestre Moisés, arrabi mor, em nome do dito seu marido da outra.

E logo pelos sobreditos foi dito que entre eles era preito e demanda por razão deste livro de Bíblia que são vinte e quatro livros que o dito Judas Navarro ora demandava ao dito arrabi mor, perante Vicente Domingues, juiz do cível na dita cidade de Lisboa, pedindo o dito Judas Navarro contra o dito arrabi mor que lhe desse o dito livro ou lhe pagasse por ele certa quantia, pela qual razão isto fazem tanto por demanda e por proposta que pelo dito juiz foi dada sentença que o dito arrabi mor lhe pagasse certa quantia, segundo diziam que mais compridamente no dito feito era conteúdo. Da qual sentença o dito arrabi apelara porque dizia a dita dona Milia pela parte do dito arrabi mor, seu marido, que o dito Judas Navarro lhe vendera o dito livro havia dois anos por noventa libras. E estando assim o dito feito para apelação ante os sobreditos perante Bartolomeu Martins e João Afonso Fuseiro, sobrejuízes do dito senhor Rei e as sobreditas partes para partirem ante si por direito e demanda que se poderiam seguir no dito feito, vieram a tal avença e amigável composição em [....ora?] de [...........] com quinhão cumprido desde logo que sobre isto filhou que o dito arrabi mor desse e pagasse ao dito Judas Navarro por todo o direito e acção que contra ele havia ou entendia

206 BnF, ms. héb. 21, fols. 295v-296r (vide nota 60, supra). 
de haver por razão do dito livro e custas e despesas que assim fizera mil e seiscentos libras desta moeda que ora corre real por dez soldos. E que o dito Judas Navarro desse por quite e por livre o dito arrabi mor e aos que dele viessem deste dia para todo sempre por razão do dito livro e das custas dele que assim sobre ele fizeram e que se obrigasse de lho defender e amparar o dito livro de quem quer que lho embargasse.

E logo o dito Judas Navarro disse que lhe praz de todo e conheceu e confessou que recebeu do dito arrabi mor as ditas mil e seiscentas libras por mão da dita dona ${ }_{296 r}$ Milia em espécies [?] desta moeda real por dez soldos pelas quais mil e seiscentas libras que assim confessou que recebeu pela guisa que sobre dito é, o deu por quite e por livre deste dia para todo o sempre, assim ao dito arrabi mor como a todos os outros que depois dele vierem, assim do dito livro como das custas e despesas que sobre ele fizera até ao dia de hoje. E mandou e outorgou o dito Judas Navarro bom o dito quinhão que assim filhou que o dito arrabi mor e os que dele vierem hajam o dito livro para si livre e isento sem embargo e contenda nenhuma que seja. E obrigou-se o dito Judas Navarro com o dito quinhão cumprido desde logo que assim filhou, a despender e amparar o dito livro ao dito arrabi mor e aos que dele vierem de quem quer que lhe demandar ou the puser sobre ele algum embargo ou lhe fizer sobre ele alguma demanda sem sua perda e em [?] dano. E não o livrando e quitando que lhe paguem as ditas mil e seiscentas libras com todas as custas e despesas e perdas e danos que se lhe pela dita razão seguirem e receber e toda maneira [?] livre-lhe e defende-lhe [??].

Outrossi o dito Judas Navarro com o dito quinhão cumprido desde logo que assim filhou deu por quite e por livre deste dia para todo o sempre ao dito arrabi mor e a todos os outros que dele vierem e de todos os preitos e demandas que ante ele havia por qualquer razão e sobre qualquer coisa que seja até ao dia de hoje.

E renunciou o dito Judas Navarro com o dito quinhão cumprido desde logo que assim filhou todo erro e engano que em esta quitação pode ser achado que recebeu o quitou e o deu por quite e por livre deste dia para todo sempre assim como se dele fosse sabedor, a qual avença e quitação o dito Judas Navarro se obrigou a cumprir e manter em tudo e por tudo pela guisa que sobredito é, sem condição e sem [?] destas [?] e desfazimento de todos os modos de protestações e protestou e protestar contra pessoa [?] nenhuma com [posgamentos??] e fortaleza deste instrumento como sobredito é, receber sobre si o dito Judas Navarro como [...?] e firmidões e [posgamento??] de todo os instrumentos que se fazem e usam entre os judeus deste dia para sempre e lhe [montem?] de todos seus bens 
móvil e raiz, raiz bem e móvil ganhados e por ganhar que o dito Judas Navarro por isto obrigou com o dito quinhão comprido desde logo que assim filhou. $\mathrm{E}$ filhámos quinhão da mão de Judas Navarro e sobredito para o arrabi mor o sobredito sobre todo o que é escrito e declarado em cima quinhão cumprido desde logo com coisa que pertence de filharmos cumpria o quinto, segundo o decreto dos judeus o [...?] das quais coisas a dita dona Milia em nome do dito arrabi mor pediu um, dois e três instrumentos para pôr [?] um deles em este livro como [...] na mão [...] do todo o seu direito e quais actos [?] lhe cumprir e [...] que mostrará [?]. Feitos no dito logo, dia, anos, era sobresitos. Testemunhas que presentes estiveram: Necim Crespim, escrivão da dita comuna, e Liote, especieiro, e José Branco, especieiro, e outros, e eu sobredito tabelião que os sobrescrevi e outro tal para o dito Judas Navarro. Os quais todos estão assinados na nota (?) e meu sinal aqui fiz que ele é [...].

[SINAL]

[Assinaturas em hebraico:] Nissim b. R. Moše Ibn Crispin; Yosef b. R. Moše Bedarrida (?)

[Uma em português:] Jento especieiro 